UNIVERSIDAD AUTÓNOMA METROPOLITANA

UNIDAD IZTAPALAPA

DIVISIÓN DE CIENCIAS BIOLÓGICAS Y DE LA SALUD

MAESTRÍA EN BIOLOGÍA DE LA REPRODUCCIÓN ANIMAL

\title{
DETECCIÓN DE LAS CASPASAS 3 Y 7 ACTIVAS, Y DE ALGUNOS DE SUS SUBSTRATOS DIVIDIDOS, EN LOS DIFERENTES TIPOS DE CÉLULAS GERMINALES DE LA RATA MACHO.
}

\author{
T E S I S \\ QUE PARA OBTENER EL GRADO DE MAESTRA EN BIOLOGÍA DE LA \\ REPRODUCCIÓN ANIMAL \\ P R E S E N T A: \\ BIÓL. CINDY URSULA RIVAS ARZALUZ. \\ Director de Tesis \\ Dr. Andrés Aragón Martínez \\ Asesores \\ Dr. Pablo G. Damián Matsumura \\ Dr. Eduardo Casas Hernández
}

México D.F. Febrero 2014. 


\title{
Miembros del comité tutorial
}

\section{Director}

Dr. Andrés Aragón Martínez

Universidad Autónoma Metropolitana-Unidad Iztapalapa

División de Ciencias Biológicas y de la Salud

Departamento Biología de la Reproducción

armandres@gmail.com

\author{
Asesores \\ Dr. Pablo Gustavo Damián Matzumura \\ Universidad Autónoma Metropolitana-Unidad Iztapalapa \\ División de Ciencias Biológicas y de la Salud \\ Departamento Biología de la Reproducción \\ pgdm@xanum.uam.mx \\ Dr. Eduardo Casas Hernández \\ Universidad Autónoma Metropolitana-Unidad Iztapalapa \\ División de Ciencias Biológicas y de la Salud \\ Departamento Ciencias de la Salud \\ dino@xanum.uam.mx
}




\section{Miembros del Jurado de Examen}

Dra. Edith Arenas Ríos

Universidad Autónoma Metropolitana-Unidad Iztapalapa

División de Ciencias Biológicas y de la Salud

Departamento Biología de la Reproducción

editharenas2000@yahoo.com.mx

Dra. Rosalina María de Lourdes Reyes Luna

Benemérita Universidad Autónoma de Puebla

Escuela de Biología

rreyesluna@hotmail.com

Dr. Pablo Gustavo Damián Matzumura

Universidad Autónoma Metropolitana-Unidad Iztapalapa

División de Ciencias Biológicas y de la Salud

Departamento Biología de la Reproducción

pgdm@xanum.uam.mx

Dr. Eduardo Casas Hernández

Universidad Autónoma Metropolitana-Unidad Iztapalapa

División de Ciencias Biológicas y de la Salud

Departamento Ciencias de la Salud

dino@xanum.uam.mx 


\section{Agradecimientos}

El Programa de Maestría en Biología de la Reproducción Animal de la Universidad Autónoma Metropolitana pertenece al Programa Nacional de Posgrados de Calidad del CONACyT (PNPC) y cuenta con apoyo del mismo Consejo.

Ésta tesis fue apoyada por la UAM-Iztapalapa, mediante la beca para alumnos de posgrado de nueva creación o en proceso de consolidación para su incorporación al PNPC, correspondiente al acuerdo 02/2011 del Rector General; así como también por la beca otorgada por el CONACyT con número de becario 302935/CRA.

El presente trabajo se realizó en el laboratorio de Fisiología de la Reproducción de la Universidad Autónoma Metropolitana Unidad Iztapalapa, bajo la dirección del Dr. Andrés Aragón Martínez; en el Laboratorio de Pubertad a cargo de la Dra. María Elena Ayala Escobar, y en el área de Citometría de Flujo con el apoyo de Guadalupe Gómez García de la Unidad de Investigación Multidisciplinaria de la Facultad de Estudios Superiores Zaragoza de la Universidad Nacional Autónoma de México.

A los revisores de la tesis y miembros del jurado de examen Dr. Pablo Damián Matsumura, Dra. Edith Arenas Ríos, Dra. Rosalina Reyes Luna, Dr. Eduardo Casas Hernández por sus acertados y oportunos comentarios y sugerencias al escrito. 
Miembros del Jurado de examen

Los miembros del jurado designado por la División de Ciencias Biológicas y de la Salud, Universidad Autónoma Metropolitana-Iztapalapa, abajo firmantes, aprobaron la tesis titulada:

"Detección de las caspasas 3 y 7 activas, y de algunos de sus substratos divididos, en los diferentes tipos de células germinales de la rata macho" con fecha del 13 de Febrero de 2014.

Presidente

Dr. Pablo Gustavo Damián Matsumura

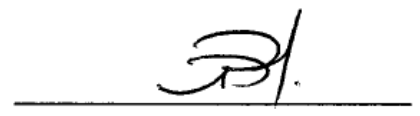

Secretario

Dra. Edith Arenas Ríos

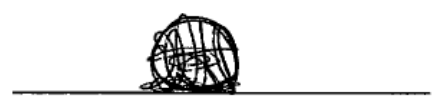

Vocales

Dr. Eduardo Casas Hernández

Dr. Miguel Ángel León Galván

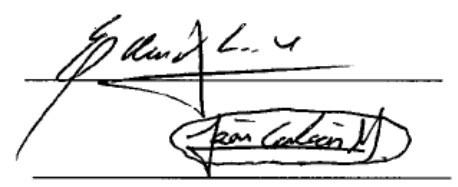


"Los sueños son sumamente importantes, nada se hace sin que antes se imagine” George Lucas.

Gracias, muchas gracias a todos los que directa e indirectamente participaron para que este sueño se hiciera realidad. A mi familia, amigos y compañeros. Sin duda, esto no hubiera sido posible sin su invaluable apoyo.

A los miembros del grupo de trabajo: Dr. Andrés AM, Claudia Morales, Luis Becerril, Jesús Quezada. Gracias por su amistad, compañía y colaboración. 


\section{ÍNDICE}

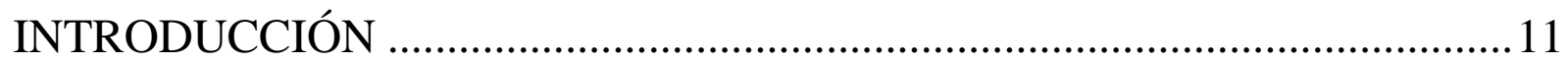

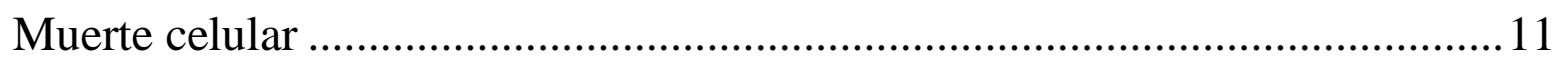

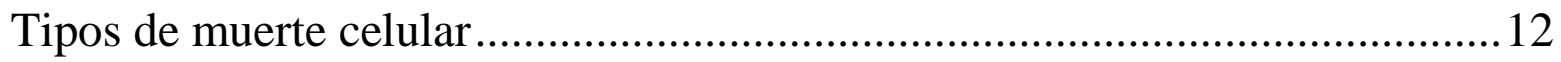

Participación de las caspasas en la apoptosis................................................15

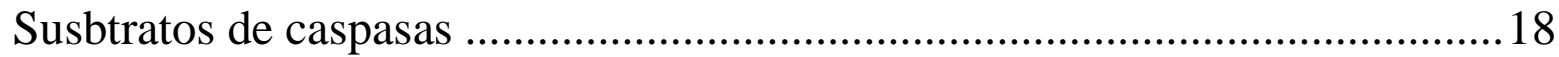

Papel de las caspasas activas en procesos celulares no letales ........................21

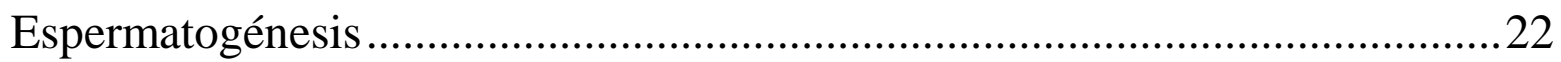

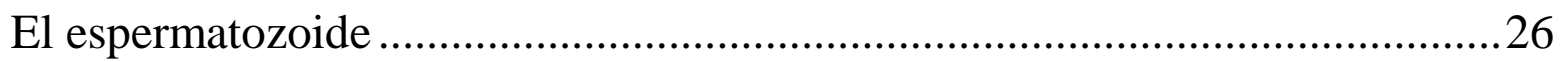

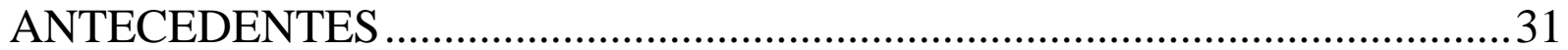

Presencia de caspasas activas en espermatozoides ..........................................34

Inducción de caspasas activas en espermatozoides .........................................35

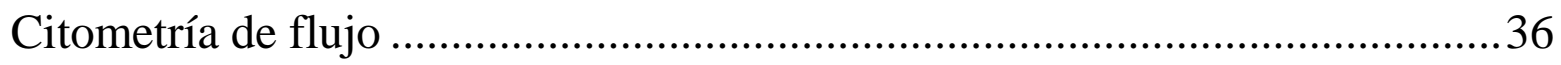

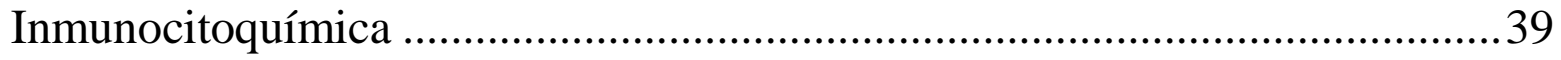

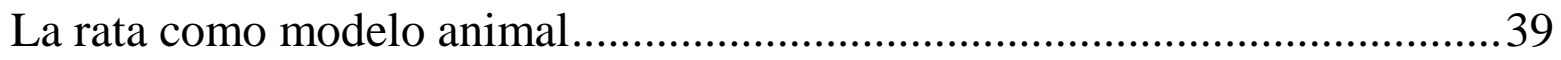

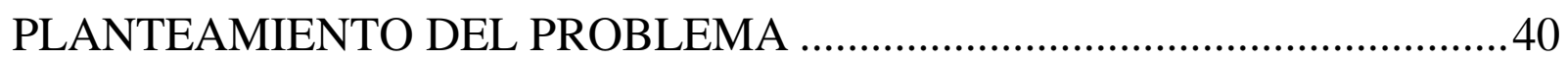

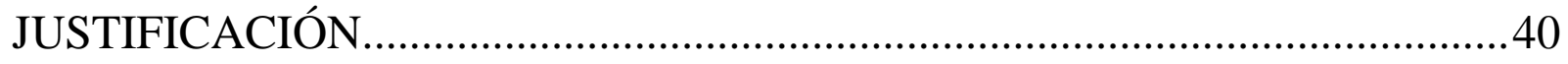

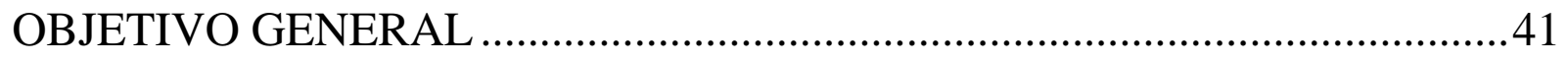

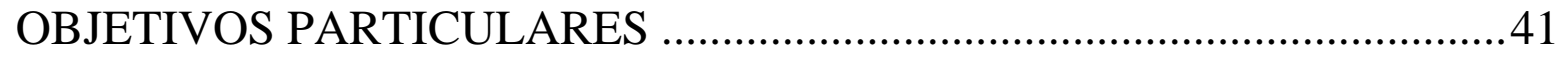

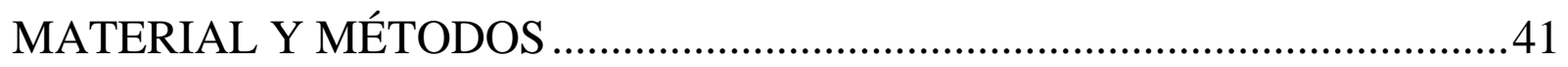

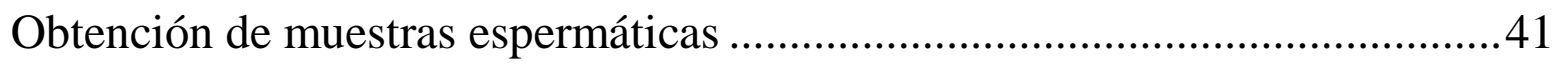

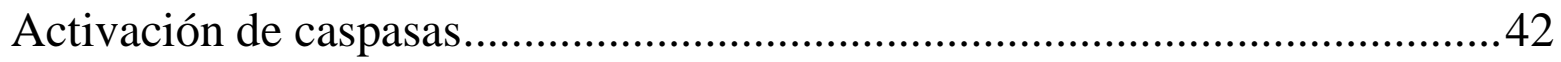

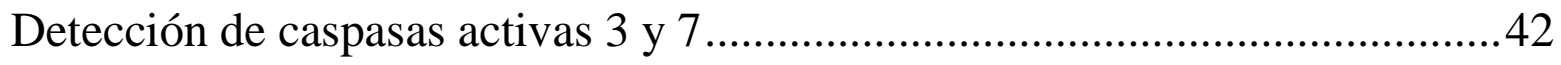

Detección y cuantificación de los substratos divididos de caspasas..................43

Análisis en microscopía de fluorescencia .....................................................44 


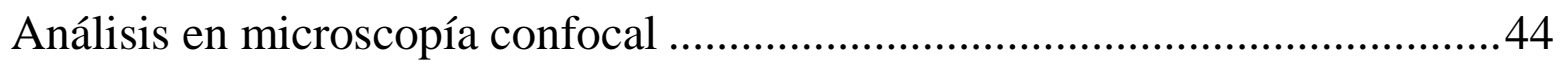

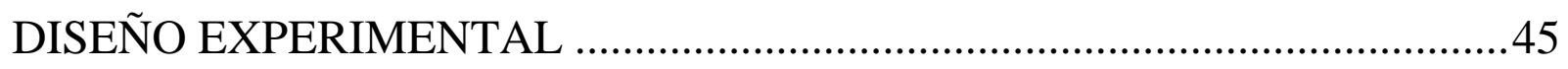

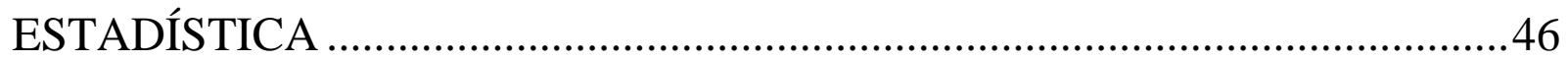

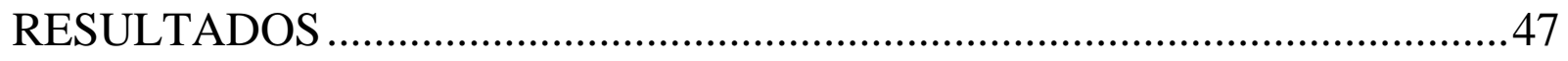

Expresión de caspasas activas 3 y 7 ................................................................... 47

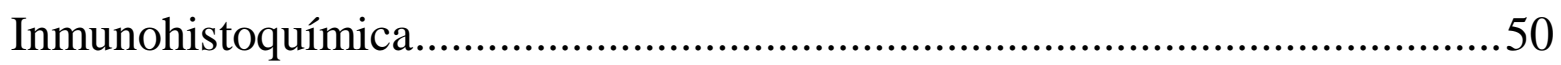

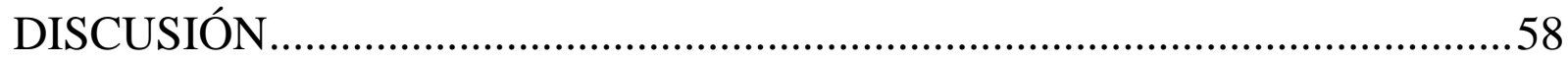

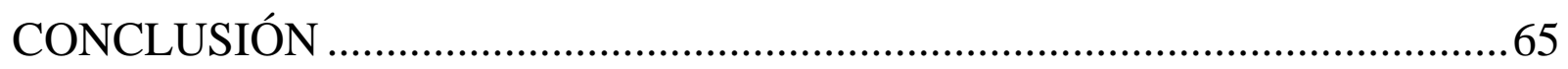

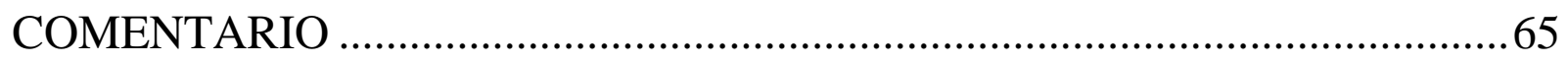

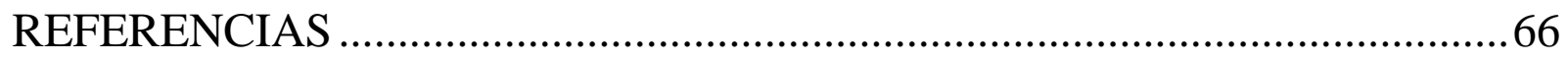




\section{Resumen}

En las células somáticas y germinales testiculares que mueren por apoptosis, se ha reportado que las caspasas 3 y 7 activas tienen un efecto proteolítico sobre diversas proteínas. Aunque se ha descrito la expresión de las caspasas activas en los espermatozoides de diferentes especies, aún se desconoce cuál es la función de tales proteínas en los gametos masculinos. El objetivo del presente trabajo fue detectar la presencia de las caspasas 3 y 7, y de algunos de sus substratos divididos, en los espermatozoides y en los diferentes tipos de células germinales testiculares. Para inducir la expresión de las caspasas activas en los espermatozoides de conductos deferentes, obtenidos de ratas control, se utilizó imiquimod y para detectar a las caspasas activas se utilizó al inhibidor fluorescente FLICA; mientras que para inducir la apoptosis de las células germinales testiculares se inyectó, por vía intraperitoneal, pcloroanfetamina a ratas adultas. Se utilizaron anticuerpos específicos para detectar por inmunohistoquímica la presencia de la caspasa 3 y 7 activas y de los fragmentos divididos de la alfa fodrina y de PARP. La detección de los espermatozoides con expresión de las caspasas activas se realizó por citometría de flujo, mientras que la expresión de las caspasas activas y de sus fragmentos divididos en el tejido testicular se realizó por microscopía de fluorescencia y confocal. El porcentaje de espermatozoides con expresión de caspasas activas, marcadas con FLICA, fue significativamente mayor cuando la incubación se realizó en presencia del inductor imiquimod (62.7 \pm 2.99 vs $96.7 \pm 1.71)$. No fue posible detectar en los espermatozoides, mediante inmunocitoquímica, a las caspasas activas ni a sus proteínas blanco divididas. En el tejido testicular se detectó la expresión de las caspasas activas, y de su proteínas blanco divididas, en las espermatogonias, los espematocitos y en las espermátidas, pero no en los espermatozoides testiculares. En el caso de las espermátidas alargadas, prontas a liberarse hacia el lumen del túbulo seminífero, la marca de alfa fodrina se observó en la región de las células que da origen a la gota citoplasmática. Nuestros resultados indican que es posible detectar por inmunohistoquímica a las caspasas activas y a sus proteínas blanco divididas, y que esta marca no está presente en los espermatozoides. Lo anterior explica la no detección inmunocitoquímica de los fragmentos divididos en los espermatozoides obtenidos a partir de los conductos deferentes. 


\section{Abstract}

In somatic cells and testicular germ cells that die for apoptosis, it has been reported that active caspases 3 and 7 have a proteolytic effect on diverse proteins. Although expression of the active caspases in sperm of different species has been described, is still unknown the function of such proteins in the male gametes. The aim of this study was to detected the presence of caspase 3 and 7, and some of their divided substrates, in sperm and in different types of testicular germ cells. Expression of active caspases in spermatozoa of vas deferens, obtained from control rats, was induced by imiquimod and to detect the active caspases was used the fluorescent inhibitor FLICA; while induction of apoptosis of testicular germ cells was realized by an intraperitoneally injection of p-chloroamphetamine to adult rats. Specific antibodies were used to detect by immunohistochemistry the presence of active caspase 3 and 7, and the divided fragments of alpha-fodrin and PARP. The detection of the spermatozoa with expression of active caspases was realized by flow cytometry, and detection of active caspases and their divided substrates in testicular tissue was conducted by fluorescence and confocal microscopy. The percentage of sperm with expression of active caspases, increased significantly when the incubation was realized in the presence of the apoptosis inducer imiquimod (62.7 \pm 2.99 vs 96.7 \pm 1.71$)$. Either active caspases nor their divided subtrates were detected by immunocytochemistry. In testicular tissue active caspases and their divided subtrates were observed in spermatogonia, spermatocytes and spermatids, but no in the testicular sperm. In elongated spermatids, ready to be released toward the lumen of the seminiferous tubule, immunostain of alpha fodrin was observed in the region that gives rise to the cytoplasmic droplets. Our results indicate that in testicular tissue it is possible to detect, by immunohistochemistry, to the active caspases and their divided substrates, although detection is negative in testicular sperm. The previous explains the non immunocytochemical detection of the fragments divided into the spermatozoa obtained from the vas deferens. 


\section{INTRODUCCIÓN}

La infertilidad es una condición que afecta al 15\% de las parejas humanas en edad reproductiva (Cooke y Saunders, 2002). La etiología de la infertilidad incluye múltiples factores, entre los que se encuentran factores ambientales, conductuales y genéticos (Cooke y Saunders, 2002; García et al., 2010). El 20\% de los casos de infertilidad son secundarios al factor masculino mientras que el $50 \%$ de todos los casos tienen un componente masculino (Alshahrani et al., 2013).

La calidad y la función espermática pueden verse afectadas por los efectos directos o indirectos durante el desarrollo de la células germinales, tales como los cambios hormonales inducidos y los efectos sobre las células somáticas testiculares que alteran el microambiente necesario para el desarrollo normal de las células germinales (Wyrobek, 1993); sin embargo, poco se sabe acerca de los aspectos orgánicos, celulares o moleculares que originan la infertilidad masculina (Celik-Ozencil y Tasatargil, 2013).

Existen diferentes ensayos que permiten evaluar aspectos funcionales de un espermatozoide. La finalidad de la evaluación espermática va dirigida generalmente al conocimiento del potencial de fertilización; sin embargo, los resultados de ésta evaluación nos ofrecen sólo una visión parcial de la capacidad fertilizante del gameto masculino. Hasta la fecha no se conoce un ensayo o marcador de calidad espermática que garantice que un espermatozoide o muestra de espermatozoides sean capaces de fertilizar (Amann y Hammerstedt, 2002; Aragón y Becerril, 2012).

\section{Muerte celular}

La muerte es parte del desarrollo normal y del ciclo de maduración celular; es el componente de muchos patrones de respuesta de tejidos vivos a compuestos xenobióticos y a modulaciones endógenas (Kanduc et al., 2002).

Los diferentes tipos de muerte celular pueden ser definidos por criterios morfológicos, enzimáticos, aspectos funcionales o inmunes. El Comité de Nomenclatura de Muerte Celular (NCCD, por sus siglas en inglés) sugiere unificar criterios para definir la muerte celular y las 
diferentes morfologías de muerte celular. El proceso de muerte ocurre por diferentes mecanismos y no ocurre de manera sincrónica en una población celular, es decir, podemos observar células en diferentes etapas del proceso de muerte (Kroemer et al., 2005; Kroemer et al., 2009); por lo que resulta importante discriminar entre una célula que está muriendo y una célula muerta.

De acuerdo al NCCD se considera muerte celular cuando cualquiera de los siguientes criterios moleculares o morfológicos se presenten: 1) las células pierden integridad de la membrana plasmática; 2) la célula y su núcleo, se fragmentan completamente en los llamados cuerpos apoptóticos; 3) los cuerpos apoptóticos son fagocitados por una célula adyacente in vivo (Kroemer et al 2009). Se ha propuesto que las células destinadas a morir pasan por un "punto de no retorno”, que es caracterizado por una activación masiva de caspasas, pérdida del potencial de membrana mitocondrial, una completa permeabilización de la membrana mitocondrial externa o la exposición de residuos de fosfatidilserina. Sin embargo, muchas de estas características no necesariamente culminan en la muerte celular (Kroemer et al., 2005; Kroemer et al., 2009).

\section{Tipos de muerte celular}

Se conocen tres distintas rutas principales de catabolismo celular que son definidas de acuerdo a los criterios morfológicos: necrosis, autofagia y apoptosis (Kroemer et al 2009).

\section{Necrosis}

La muerte celular necrótica o necrosis está caracterizada morfológicamente por la ganancia de volumen celular (oncosis), encogimiento de organelos, ruptura de la membrana plasmática, pérdida de contenido intracelular, una cromatina compactada de manera uniforme al inicio del proceso; mientras que al disminuir el tamaño del núcleo y al romperse la membrana citoplasmática, la cromatina se observa como pequeñas masas discretas. En este tipo de muerte las células vecinas son afectadas, mientras que en los tejidos adyacentes se observa inflamación exudativa. Los restos celulares son fagocitados por células fagocitarias especializadas (Kroemer et al., 2009). 
La necrosis es el término utilizado actualmente para describir a un tipo de muerte celular no apoptótica y accidental. Se utiliza en patología para designar la presencia de tejido o células muertas y el total de cambios que ocurren en las células después de que mueren independientemente del proceso de muerte (Fink et al., 2005).

La necrosis se ha considerado, por mucho tiempo, como una forma de muerte celular descontrolada y accidental, aunque existe evidencia de que la ejecución de la necrosis puede ser regulada por rutas de transducción de señales y mecanismos catabólicos (Kroemer et al., 2009).

\section{Autofagia}

La autofagia es un proceso evolutivamente conservado que comienza con la formación de autofagosomas, estructuras de doble membrana, que rodean macromoléculas citoplásmicas y organelos para su degradación (Ouyang et al., 2012). La formación de autofagosomas es controlado por GTPasas y fosfatildilinositol cinasas. Los autofagosomas se fusionan con lisosomas en un proceso dependiente de microtúbulos, para posteriormente ser degradados (Fink et al., 2005).

La presencia de la autofagia ha sido descrita durante el desarrollo de los vertebrados, ocurre como parte de las actividades diarias de una célula en respuesta a estrés metabólico o hipóxico (Gallardo-Bolaños et al., 2012). La autofagia controla una variedad de procesos fisiológicos, como la estivación, la diferenciación celular, la sobrevivencia y la muerte celular (Fink et al., 2005). En general, la autofagia es un mecanismo que responde al estrés intra y extra celular e implica la sobrevivencia celular en ciertas circunstancias como un mecanismo para degradar proteínas dañadas de manera irreversible; sin embargo, una sobre activación de la autofagia podría resultar en la muerte celular autofágica (Ouyang et al., 2012).

\section{Apoptosis independiente de caspasas}

Se considera como apoptosis independiente de caspasas a un tipo de muerte celular inducida por modificaciones genéticas o por inhibidores. La muerte celular independiente de caspasas 
puede ocurrir a pesar de la inhibición efectiva de caspasas y se puede manifestar con señales morfológicas de apoptosis, autofagia o necrosis (Kroemer et al., 2005).

\section{Apoptosis dependiente de caspasas}

La apoptosis constituye un fenómeno importante ya que centra su atención en el intercambio natural de células, necesario para mantener un organismo sano. Se distingue de la necrosis en la cual se produce lisis de las membranas celulares, vaciamiento del contenido lisosomal e inflamación (Kawa, 2000). La palabra “apoptosis” fue acuñada por Kerr et al (1972), quienes describieron este tipo de muerte celular desde un punto de vista meramente morfológico.

La apoptosis es un proceso controlado genéticamente y dependiente de energía, mediante el cual los organismos eliminan células innecesarias o dañadas, regula la proliferación celular y se divide en tres fases: inicio, ejecución y degradación (Ortega-Ferrusola et al., 2008). La apoptosis afecta a células individuales y no a las células adyacentes. El término apoptosis es usado como sinónimo de muerte celular programada; sin embargo, de acuerdo al NCCD , es incorrecto asumir que son sinónimos debido a que la muerte celular programada ocurre durante el desarrollo fisiológico y presenta características no apoptóticas (Bjelakovic et al., 2005; Kroemer et al., 2009).

En las células de mamíferos, la apoptosis puede ser iniciada por una variedad de estímulos del ambiente intra y extra celular (Earnshaw et al., 1999). La apoptosis juega un papel crucial en los organismos multicelulares durante el desarrollo temprano, pues esculpe partes corporales mientras que en la vida adulta controla el número celular (Saikumar y Venkatachalam, 2009). La apoptosis es un evento fundamental en el mantenimiento de la homeostasis celular (Marchetti y Marchetti, 2007) y ha sido observado en células somáticas y germinales testiculares (Aragón et al., 2005; Aragón y Becerril, 2012).

La apoptosis es caracterizada morfológicamente por una reducción en el volumen celular y nuclear, por la condensación de la cromatina, por la degradación del ADN en fragmentos oligonucleosomales, por la preservación de los organelos y de la integridad de la membrana plasmática; así como por la fragmentación celular que da lugar a los llamados cuerpos 
apoptóticos (Kerr et al., 1972; Pereira y Amarante-Mendes, 2011). La composición de los cuerpos apoptóticos puede variar, algunos contienen uno o más fragmentos nucleares y citoplasma condensado, mientras que otros contienen solo elementos citoplásmicos (Wyllie, 2010).

\section{Participación de las caspasas en la apoptosis}

Las caspasas son una familia de proteasas de cisteína dependientes del ácido aspártico, que se ha conservado a lo largo de la evolución, capaces de dividir a su proteína blanco al reconocer un residuo de ácido aspártico. Las caspasas son sintetizadas como zimógenos o enzimas inactivas, permanecen en el espacio intermembranal de la mitocondria, en el retículo endoplásmico, en el aparato de Golgi, en el citosol y en el núcleo (Köhler et al., 2002), y son liberadas al citosol para ser activadas mediante una cascada de reacciones proteolíticas (Ulukaya et al., 2011; Ruwanpura et al., 2010). La translocación intracelular de las caspasas activas es un paso crítico para el desarrollo del proceso apoptótico (Vaculova y Zhivotovsky, 2008).

Las caspasas son las únicas proteasas que median los principales cambios morfológicos de la apoptosis y varios procesos de remodelación celular. Su activación puede indicar el inicio de la diferenciación, la inflamación y otros procesos vitales (Crawford y Wells, 2011).

Las caspasas se encuentran exclusivamente en los metazoarios, y su número y tipos varían entre organismos, lo cual indica diversidad en las funciones de estas enzimas (Crawford y Wells, 2011; Fuentes-Prior y Salvesen, 2004). Hasta la fecha, se han identificado 14 distintas caspasas en los mamíferos (Shi 2009). Dependiendo de su función, se distinguen tres grupos de caspasas: las caspasas iniciadoras (2, 8, 9, 10), las caspasas efectoras (3, 6, y 7) y las caspasas involucradas en los procesos inflamatorios $(1,4,5,11,13)$ (Faleiro y Lazebnik, 2000).

La activación de una caspasa efectora, como la caspasa 3 o 7, es llevada a cabo por una caspasa iniciadora, la caspasa 9, mediante divisiones internas para separar las subunidades largas y cortas. Las caspasas iniciadoras son autoactivadas en condiciones apoptóticas. Una 
vez activadas, las caspasas dividen substratos específicos en diferentes compartimentos celulares (Köhler et al., 2002; Shi 2009).

Las principales rutas de activación de las caspasas descrita en mamíferos son la intrínseca y extrínseca (Chowdhury et al., 2008) (Figura 1). La ruta intrínseca es iniciada por señales intracelulares como el daño en el $\mathrm{ADN}$, lo que causa la activación de miembros proapoptóticos de la familia Bcl-2, los cuales llevan a la liberación de factores proapoptóticos del espacio intermembranal de la mitocondria hacia el citoplasma (Chowdhury et al., 2008; Shi 2009).

En la ruta intrínseca, uno de los principales eventos es la permeabilización de la membrana externa de la mitocondria, la cual es llevada a cabo por proteínas proapoptóticos como Bax y Bak. Como consecuencia del estímulo apoptótico las proteínas proapoptóticas presentan cambios conformacionales y oligomerización lo que causa la desestabilización de la bicapa lipídica mediante la formación de poros de Bax y Bak y/o canales que permiten la salida del citocromo c del espacio intermembranal y la consecuente permeabilización de la membrana mitocondrial externa (D’Amelio et al., 2010).

La permeabilización de la membrana mitocondrial permite la salida del citocromo c hacia el citosol, en donde, en presencia de dATP, se une al factor activador de proteasa apoptótica-1 (Apaf-1) para formar el complejo macromolecular llamado apoptosoma. Este complejo se une y activa a la procaspasa 9, la cual activa las caspasas efectoras 3 y 7 (Chowdhury et al., 2008; D’Amelio et al., 2010), que a su vez provoca una cascada de división y activación de caspasas (Shi 2009). La ruta intrínseca es responsable del inicio de la apoptosis en respuesta a estímulos tales como la radiación, algunas drogas quimioterapéuticas y ciertas señales durante el desarrollo (Stennicke y Salvesen, 2000; Susin et al., 1997).

La vía extrínseca es mediada por los receptores de la superficie celular (Fas/CD95) que al unirse con su ligando (Fas/CD95) transmiten una señal hacia el citosol. El receptor se trimeriza y permite el reclutamiento de proteínas adaptadoras específicas. El receptor contiene un dominio de muerte (DD) en la región citoplásmica que interactúa con la proteína adaptadora formando una complejo de señalización de inducción del receptor de muerte 
(DISC) dentro del cual se recluta la procaspasa 8 mediante receptores de muerte (FADD) (Boatright y Salvesen, 2003; Ried y Scott, 2009; D’Amelio et al.,2010).

La procaspasa 8 se activa proteolíticamente y activa caspasas efectoras que se encuentran cascada abajo en la ruta de señalización apoptótica. Así mismo, la caspasa 8 media la división de Bid, un miembro proapoptótico de la familia Bcl-2. Una vez dividido, se trasloca a la mitocondria donde induce la liberación del citocromo c (D’Amelio et al., 2010). De esta manera Bid media la comunicación entre las rutas extrínseca e intrínseca (Shi 2009) (Figura 1).

Las dos vías convergen en la activación de las caspasas efectoras 3 y 7, las cuales orquestan el desmantelamiento de diversas estructuras celulares mediante la división de substratos específicos (Figura 1). Las divisiones proteicas mediadas por las caspasas producen los cambios fenotípicos observados en la célula apoptótica, tales como, el redondeo de la célula, la reducción del volumen celular, la fragmentación del núcleo, la translocación de la fosfatidilserina de la cara citoplasmática hacia la cara externa de la membrana plasmática, la formación de burbujas en la membrana citoplasmática, la pérdida del potencial de membrana mitocondrial, la fragmentación del ADN y el mantenimiento de la membrana plasmática hasta las últimas etapas del proceso (Martin et al, 1995; Kroemer et al., 2005; D’Amelio et al., 2010; Crawford y Wells, 2011).

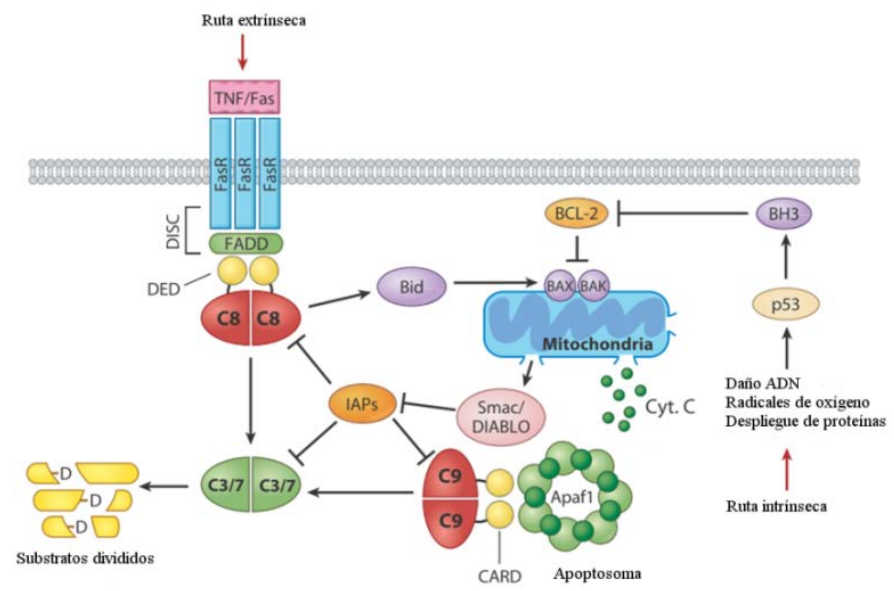

Figura 1. Rutas de activación intrínseca y extrínseca de caspasas. Modificado de Crawford y Wells., 2011. 
Las características de apoptosis en células somáticas, como la translocación de la fosfatidilserina, y la pérdida del potencial de la membrana mitocondrial, se conocen como marcadores tempranos de apoptosis (Martin et al., 1995; Marchetti et al., 2002); mientras que, el daño en el ADN y la presencia de caspasas activas, se consideran marcadores tardíos (Taylor et al., 2004). La reducción del potencial de membrana es una característica general de la muerte celular programada, esta disminución, definida como una etapa temprana de la apoptosis, precede a otras manifestaciones de este proceso tales como la fragmentación del ADN (Marchetti et al., 2002).

El procesamiento o activación de caspasas es evaluado mediante diferentes métodos de caracterización y/o cuantificación, entre los que se encuentran el inmunomarcaje, la división de substratos sintéticos, por microscopía confocal, de fluorescencia y citometría de flujo (Köhler et al., 2002).

\section{Susbtratos de caspasas}

Las caspasas reconocen específicamente una secuencia de cuatro aminoácidos presente en sus substratos, el carboxilo terminal del ácido aspártico dentro de dicha secuencia es el blanco para que se de la división (Darzynkiewicz et al., 2011). Los substratos de caspasas son proteínas que cumplen con diferentes funciones dentro de la célula (Vaculova y Zhivotovsky, 2008), ya sea componentes estructurales del citoesqueleto y del núcleo, proteínas involucradas en rutas de señalización que inician una cascada de eventos; así como proteínas involucradas en la replicación, reparación y degradación del ADN (Vaculova y Zhivotovsky, 2008; Earnshaw et al., 1999).

Se han descrito al menos 400 diferentes substratos de caspasas. Algunos son considerados como blancos comunes para todas las células, mientras que otros son específicos para un tipo celular (Vaculova y Zhivotovsky, 2008). La división de substratos puede resultar en la inactivación o activación de las proteínas blanco. En la mayoría de los casos las proteínas son inactivadas y son principalmente proteínas del citoesqueleto como lamina, alfa-fodrina, actina y algunas proteínas involucradas en la reparación del ADN como poly(A)DP ribosa polimerasa (PARP) (Köhler et al.,2002). 
El único substrato de caspasas reportado en el espermatozoide eyaculado de humano y que es dividido durante el proceso apoptótico es la proteína PARP (Jha et al., 2009). PARP es una proteína nuclear que se encuentra involucrada en la reparación al daño en el ADN (Martin et al., 1995; Mahfouz et al., 2009). Una vez detectado el daño, PARP se une al ADN, activándose e iniciando la síntesis del polímero y promoviendo la modificación postraduccional de una serie de proteínas implicadas en la reparación del mismo (Martin-Oliva et al., 2006). Se ha observado que en humanos, la presencia de bajas concentraciones de PARP en espermatozoides maduros de pacientes infértiles comparada con los espermatozoides maduros de donadores, sugiere un papel de PARP y sus homólogos en la infertilidad masculina; además, los homólogos de PARP, PARP-1 y PARP-2, están involucrados en la maduración espermática, debido a que fracciones de espermatozoides maduros presentan una mayor concentración de estas proteínas comparado con fracciones de espermatozoides inmaduros (Jha et al., 2009).

PARP es una proteína nuclear de $116 \mathrm{kDa}$ de peso molecular implicada en la reparación del ADN y mantenimiento de la integridad genómica y regula la expresión de varias proteínas a nivel transcripcional, así como la replicación y diferenciación (Celik-Ozenci y Tasatargil, 2013). Cataliza la transferencia de unidades de ADP-ribosa procedentes del substrato $\mathrm{NAD}^{+}$ sobre los residuos de ácido glutámico y aspártico de una serie de proteínas nucleares. PARP-1 se activa principalmente en respuesta a daños en el ADN generado por diferentes agentes genotóxicos como radiación ionizante, agentes alquilantes y radicales libres. La caspasa 3 reconoce el motivo DEVD dentro de la secuencia de localización nuclear de PARP-1 y es cortada en dos fragmentos de 89 y $24 \mathrm{kDa}$. Este corte proteolítico es considerado actualmente como un marcador apoptótico. Los fragmentos generados durante dicho corte proteolítico contribuyen a la inactivación de la enzima intacta, ya que inhiben la unión de la enzima no proteolizada al ADN y su homodimerización (Martin-Oliva et al., 2006).

La poli-ADP-ribosilación de proteínas mediada por PARP es una modificación covalente de proteínas nucleares, lo que les permite modificar su función biológica en un momento determinado (Martin-Oliva et al., 2006). 
La alfa fodrina es una proteína del citoesqueleto cortical presente en la mayoría de las células eucariotas, la cual es proteolizada durante la apoptosis inducida por estaurosporina en líneas celulares de mastocitoma de murino. La división de la alfa fodrina mediante caspasas también ha sido detectada en líneas celulares de ratones y de humanos (Martin et al., 1995).

La alfa fodrina es una proteína acoplada a la membrana plasmática con asociaciones directas con actina o indirectas con la anquirina (Bennet y Gilligan, 1993). Dada la localización cortical de la fodrina en el citoesqueleto, es posible que la formación de burbujas en la membrana durante la apoptosis sea parcialmente debido a la red de fodrina (Martin et al., 1995). La proteína alfa fodrina es dividida también durante la exposición de la fosfatidilserina en la capa externa de las células (Martin et al., 1995; Fox et al., 1987).

Los principales productos de la división de la alfa-fodrina son un fragmento N-terminal de 135 kDa y dos fragmentos C-terminal de $120 \mathrm{kDa}$ y $150 \mathrm{kDa}$ (Janicke et al., 1998). Janicke et al (1998) analizaron los diferentes substratos que son divididos por caspasas, y concluyeron que la presencia y activación de la caspasa 3 son requeridas para la división de alfa-fodrina in vivo en células de cáncer de mama humano.

Una de las funciones inferidas de la proteína alfa-fodrina y de las proteínas asociadas a ella, es el ensamblaje y/o el mantenimiento de dominios especializados en la superficie celular (Bennet y Gilligan, 1993).

La presencia y localización de una de las proteínas asociadas a alfa fodrina, como la actina, se ha demostrado en el espermatozoide de diferentes especies mediante técnicas inmunológicas. Las regiones que presentan actina son el área postacrosomal, la región ecuatorial y el espacio subacrosomal, así como el cuello y la cola. Se ha observado que existen diferencias entre especies; sin embargo, una característica común a todas las especies estudiadas es su localización en el flagelo; aunque su papel en el movimiento flagelar no es claro. De manera específica, en espermatozoides de carnero, esta proteína está localizada en la cabeza, por lo que podría jugar un papel durante la fertilización (de las Heras et al., 1997). 
Se han descrito proteínas de unión a actina o que se encuentran asociadas a ésta, además de la espectrina o fodrina (Camatini et al., 1991); tal es el caso de la gelsolina (de las Heras et al., 1997), la tubulina (Aumuller y Seitz 1988), así como proteínas involucradas en los procesos de capacitación y reacción acrosomal en el espermatozoide (de las Heras et al., 1997).

La organización del citoesqueleto del espermatozoide juega un papel importante en el ensamblaje y estabilización de dominios especializados en la superficie celular y en los eventos asociados a la fertilización (Virtanen et al., 1984).

\section{Papel de las caspasas activas en procesos celulares no letales}

Se ha reportado la presencia de caspasas activas en células germinales testiculares de $D$. melanogaster (Arama et al., 2003), así como de mamíferos como la rata (Moreno et al., 2006); en espermatozoides de diferentes especies, como en humano (Wundrich et al., 2006; Brugnon et al., 2007; Grunewald et al., 2009), en ovinos (Pichardo et al., 2010; García et al., 2012), en cerdos (Morales et al., 2012), y en roedores (Cisternas y Moreno, 2006).

La caspasa 3 es el principal ejecutor de la cascada apoptótica. Su activación determina el destino de la célula; sin embargo, la activación local y la especificidad de los substratos están involucradas en mecanismos reguladores como la muerte neuronal fisiológica durante el desarrollo hasta la muerte neuronal en enfermedades neurológicas. En estudios realizados en insectos, aves y mamíferos, se ha observado que la activación de la caspasa 3 neuronal está involucrada en la plasticidad sináptica; lo anterior indica que la caspasa activa 3 tiene un papel no apoptótico, aunque el mecanismo subyacente actualmente se desconoce (D’Amelio et al., 2010).

Existe evidencia de que las caspasas tienen un papel en el aprendizaje y memoria. En el cerebro anterior del pinzón cebra, la concentración de caspasas activas 3 es mayor después de la exposición a la grabación del canto de un ave. Además, la activación de las caspasas es requerida para la consolidación de la memoria, por lo que Huesmann y Clayton (2006) propusieron que la actividad de caspasas puede ser importante para las modificaciones estructurales requeridas para la memoria. 
Las caspasas no sólo presentan papeles no apoptóticos en el sistema nervioso; en el testículo, la actividad de las caspasas es requerida para que se lleve a cabo la individualización de las espermátidas durante la diferenciación terminal (Arama et al., 2003). Lo anterior permite plantear la idea de que un mecanismo parecido a la apoptosis es requerido para que se diferencien las espermátidas en espermatozoides, ya que el objetivo de la activación de las caspasas no es la muerte celular como tal, sino la producción de una célula viva altamente especializada.

En la pieza media de los espermatozoides eyaculados de humano se localizó la caspasa 3 mediante inmunomarcaje, lo que sugiere que un proceso parecido a la apoptosis puede estar restringido a una región donde las mitocondrias, y remanentes de la gota citoplasmática, puedan estar localizadas en un espermatozoide anormal y/o inmaduro (Weng et al., 2008, García et al., 2012, Morales et al., 2012). La activación de las caspasas en los espermatozoides podría participar en la fertilidad o infertilidad, o incluso no tener ninguna función si fueran un remanente de actividad previa a la eyaculación (Taylor et al., 2004).

\section{Espermatogénesis}

Los testículos adultos llevan a cabo dos funciones esenciales: producir espermatozoides haploides y secretar hormonas esteroides sexuales. La espermatogénesis, toma aproximadamente 75 días en el humano y 45 días en la rata. En todos los mamíferos, la espermatogénesis normal y la fertilidad dependen de las interacciones entre las células somáticas (Sertoli, Leydig y peritubulares) y las células germinales, así como de las hormonas producidas por el eje hipotálamo-hipófisis-testículo (Cooke y Saunders, 2002).

La espermatogénesis es un proceso altamente regulado y sincrónico, que consiste en la transformación de espermatogonias diploides no diferenciadas en espermatozoides maduros haploides, el cuál ocurre dentro de los túbulos seminíferos, localizados en los testículos (Figura 2). El epitelio seminífero consta de células germinales que forman numerosas capas concéntricas asociadas a las células somáticas o de Sertoli. Las células de Sertoli son las encargadas de nutrir y mantener estas asociaciones celulares a lo largo del desarrollo de las células germinales (Hess y Da Franca, 2008). 
Las células germinales masculinas inmaduras se dividen, se diferencian y dan origen a espermátidas alargadas, haploides y altamente especializadas (O'Donnell et al., 2006). Las divisiones mitóticas y meióticas involucran la duplicación de los cromosomas, la recombinación genética y la reducción de cromosómica (Hess y Da Franca, 2008).
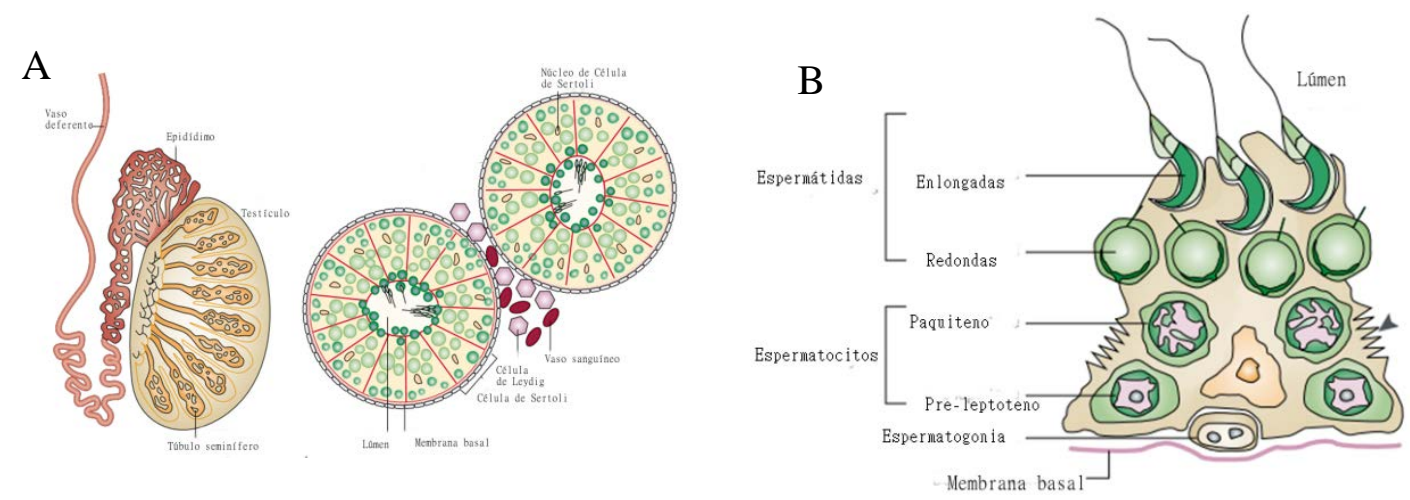

Figura 2. A. Representación esquemática de un testículo y las estructuras adyacentes, así como la espermatogénesis y los diferentes tipos celulares que participan en dicho proceso en la mayoría de los mamíferos. B. Representación esquemática de los diferentes tipos de células germinales en el epitelio seminífero de la rata.

La espermatogénesis no solo consiste en un incremento en el número de células, también está acompañado de cambios o diferenciación que involucran la forma celular, la pérdida de algunos organelos y redistribución de otros (Tapia y Peña 2009).

Al completarse la espermatogénesis, las espermátidas maduras son liberadas de las células de Sertoli hacia el lúmen del túbulo seminífero, viajan a lo largo del sistema de ductos conocido como red de testis, hasta que entran en el epidídimo mediante los túbulos rectos o eferentes (O'Donnell et al., 2006). La espermiación es la fase final de la espermatogénesis, ésta involucra la eliminación de citoplasma de las espermátidas para producir espermatozoides móviles y requiere la participación de testosterona y FSH (Ruwanpura et al., 2010). Durante la liberación del espermatozoide maduro se forma un cuerpo residual a partir de citoplasma, y es fagocitado por las células de Sertoli (Print y Loveland 2000). 
Durante el paso del espermatozoide por el epidídimo, se modifica su membrana citoplasmática, se estabiliza la cromatina y adquiere la capacidad de desplazarse de forma independiente (Tapia y Peña 2009).

El mantenimiento de la arquitectura normal del epitelio seminífero es dado por un balance entre la proliferación y la eliminación de células germinales. Este balance es determinado por la capacidad de las células de Sertoli de proveer los factores necesarios para el progreso exitoso de espermatogonia a espermatozoide; además, las células de Sertoli limitan la expansión de la población de células germinales debido a que cada una es capaz de nutrir un número definido de células germinales (Tapia y Peña 2009). Las células germinales son eliminadas por mecanismos apoptóticos que ocurren de manera normal en la espermatogénesis. Las espermatogonias, los espermatocitos y las espermátidas haploides son eliminadas selectivamente por apoptosis (Print y Loveland 2000). Se ha observado que existe una alta asociación entre las células germinales y las células de Sertoli que entran en apoptosis y exhiben externalización de la fosfatidilserina, característica de la apoptosis en células somáticas (Tesarik et al., 2004).

La espermatogénesis es controlada por la secreción hipotalámica de la hormona liberadora de gonadotropinas (GnRH) que estimula la secreción de la hormona folículo estimulante (FSH) y de la hormona luteinizante (LH). La LH actúa en el testículo para producir testosterona y para mantener la espermatogénesis (Sutovsky y Manandhar, 2006). Tanto la proliferación y sobrevivencia de las células germinales masculinas depende de los mecanismos dependientes de gonadotropinas (Figura 3). La FSH ejerce sus efectos biológicos mediante receptores a FSH acoplados a proteínas G (FSHRs) que se encuentran en la membrana citoplasmática de las células de Sertoli. La señalización por FSH activa a proteínas de unión a elementos de respuesta al AMPc (CREB), que luego transcriben los genes blanco de la espermatogénesis (Ruwanpura et al., 2010).

La testosterona es sintetizada en las células de Leydig después de ser estimuladas por LH. La testosterona ejerce sus efectos mediante receptores de andrógenos (ARs) localizados en las células de Sertoli (Ruwanpura et al., 2010). 
El tamaño de la población de las células de Sertoli es establecido en la vida postnatal, y es el principal determinante de la cantidad de espermatozoides en la vida adulta. Cuando inicia la espermatogénesis, las células de Sertoli entran en un periodo de proliferación en donde la FSH es un importante regulador (Ruwanpura et al.,2010).

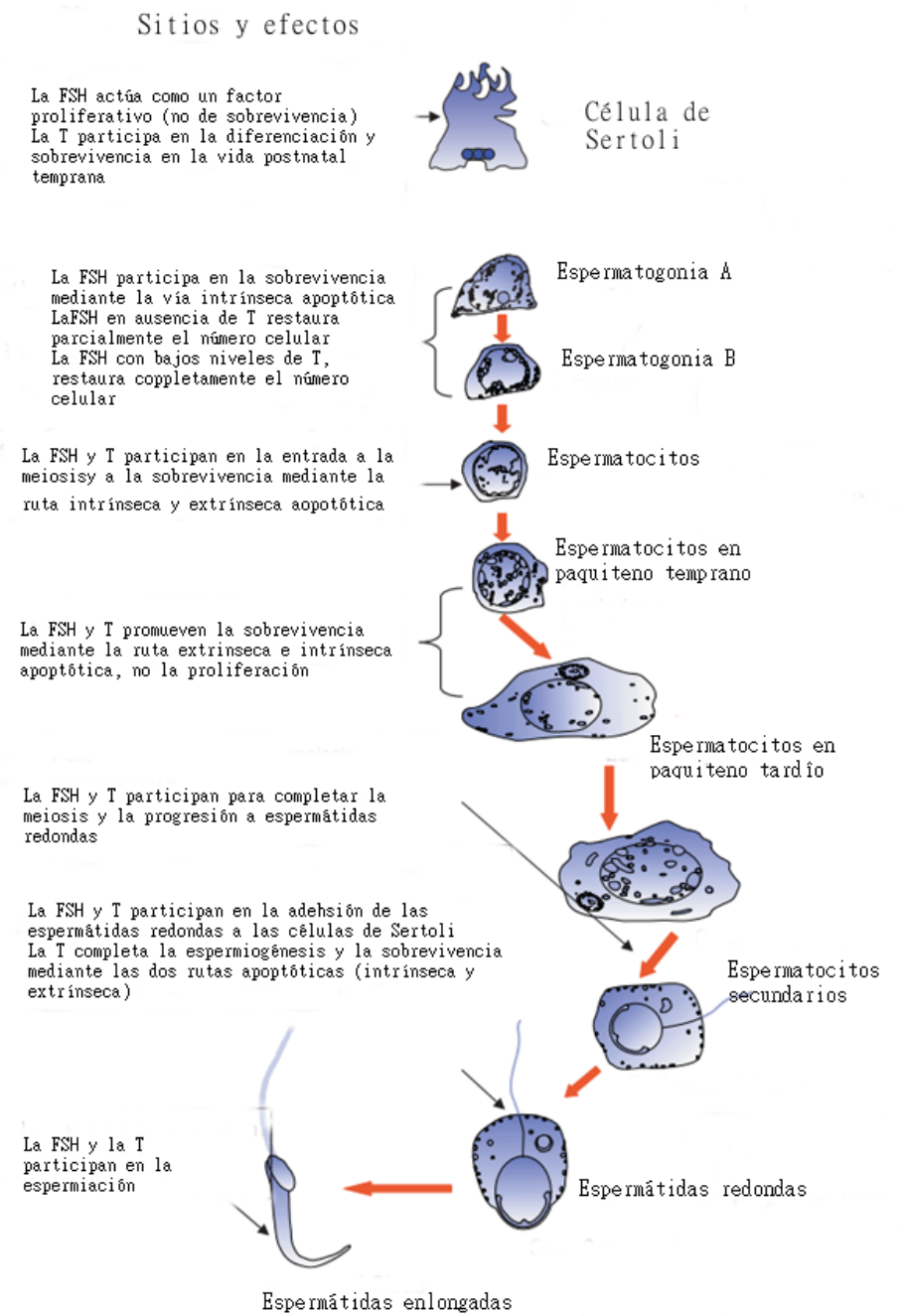

Figura 3. Diagrama que representa la regulación hormonal de la espermatogénesis en roedores. Se describe brevemente la participación de hormonas gonadotrópicas y testiculares en los diferentes tipos celulares durante la espermatogénesis. Tomado de Ruwanpura et al., 2010. 


\section{El espermatozoide}

Los espermatozoides de mamíferos son células altamente especializadas generadas durante la espermatogénesis (Tapia y Peña 2009). Desde el punto de vista morfológico, se distinguen dos estructuras principales en el espermatozoide: la cabeza y el flagelo (Figura 4), los cuales se encuentran unidos por la pieza conectora y recubiertos por la membrana citoplasmática. La cabeza contiene el núcleo, el acrosoma, estructuras del citoesqueleto, y una pequeña cantidad de citoplasma. El núcleo contiene la cromatina altamente condensada con información genética. Anterior al núcleo se encuentra el acrosoma que contiene enzimas hidrolíticas (Eddy, 2006; Sutovsky y Manandhar, 2006).

Las características estructurales especializadas del espermatozoide de mamíferos reflejan las funciones únicas de éste tipo celular. En muchos mamíferos, el cromosoma sexual en el núcleo haploide del espermatozoide determina el sexo del individuo resultante. (Eddy, 2006).

La membrana citoplasmática del espermatozoide se subdivide en dominios regionales, los cuales difieren en composición y función, por lo que se considera como un mosaico de dominios restringidos que reflejan las funciones especializadas de los componentes superficiales y citoplasmáticos del espermatozoide (Eddy, 2006). Los dominios de la membrana del espermatozoide son importantes para la función de las áreas de la membrana, por ejemplo, la membrana del segmento ecuatorial es responsable del contacto con la membrana del ovocito en la fertilización (Pesch y Bergmann, 2006).

Existen proteínas involucradas en el mantenimiento y formación de los dominios como la actina y proteínas asociadas a actina y que han sido identificadas en el espermatozoide de varios mamíferos. En el espermatozoide de rata se han localizado los filamentos de actina en la región subacrosomal. Otras proteínas asociadas a actina son la miosina y la espectrina. La miosina ha sido identificada en la región acrosomal y en la región del cuello del espermatozoide humano. La espectrina o fodrina está asociada con las espermátidas en el ratón y no es detectada en espermatozoides del epidídimo (Eddy, 2006; De Cesaris et al., 1989). 


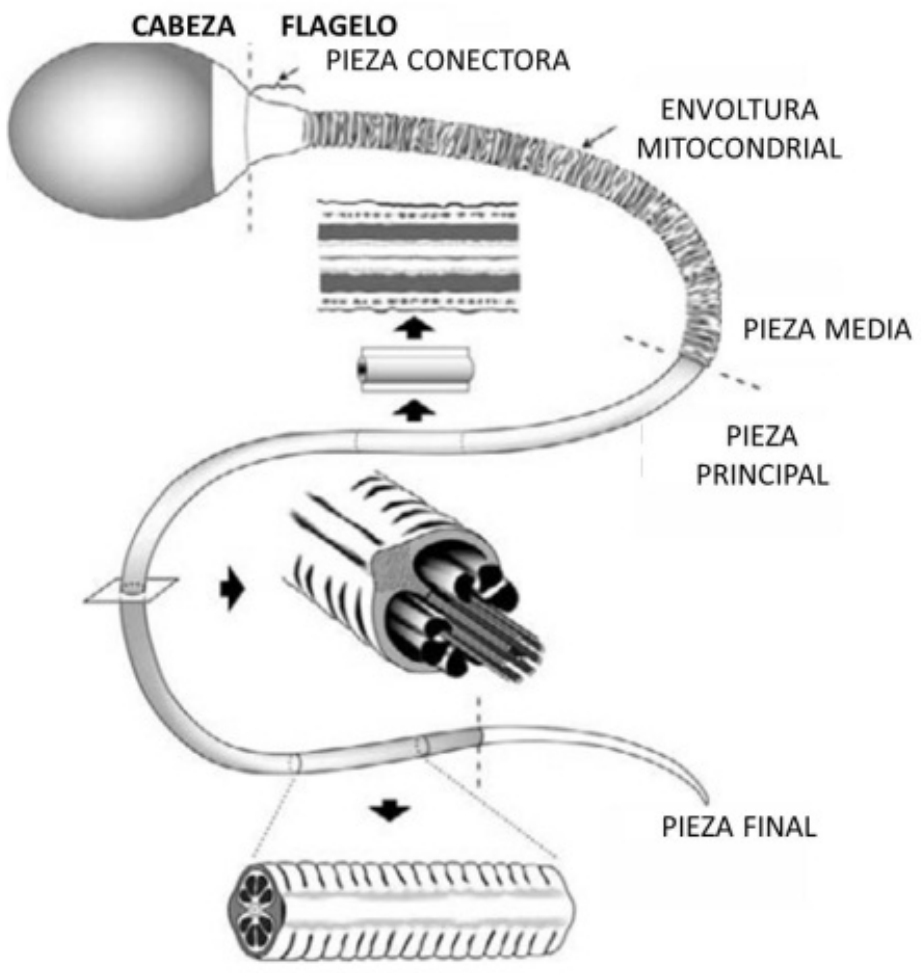

Figura 4. Características generales del espermatozoide de mamíferos. La cabeza del espermatozoide está unida al flagelo mediante la pieza conectora. Las regiones del flagelo son la pieza media, la pieza principal y la pieza final. Los cortes longitudinales y transversales de la pieza principal y del segmento de la vaina fibrosa están indicadas por las flecha. Modificada de Eddy, 2006.

La membrana citoplasmática de la cabeza se divide en la región acrosomal (anterior) y en la región postacrosomal (posterior) (Figura 5) (Eddy, 2006). El acrosoma contiene enzimas hidrolíticas como acrosina, hialuronidasa, otras hidrolasas y esterasas. Estas enzimas son esenciales para la lisis de la zona pelucida y la penetración de la corona radiada del ovocito. Las enzimas del acrosoma on liberadas durante la reacción acrosomal, cuando la membrana acrosomal externa se une con la membrana plasmática (Pesch y Bergmann, 2006). 


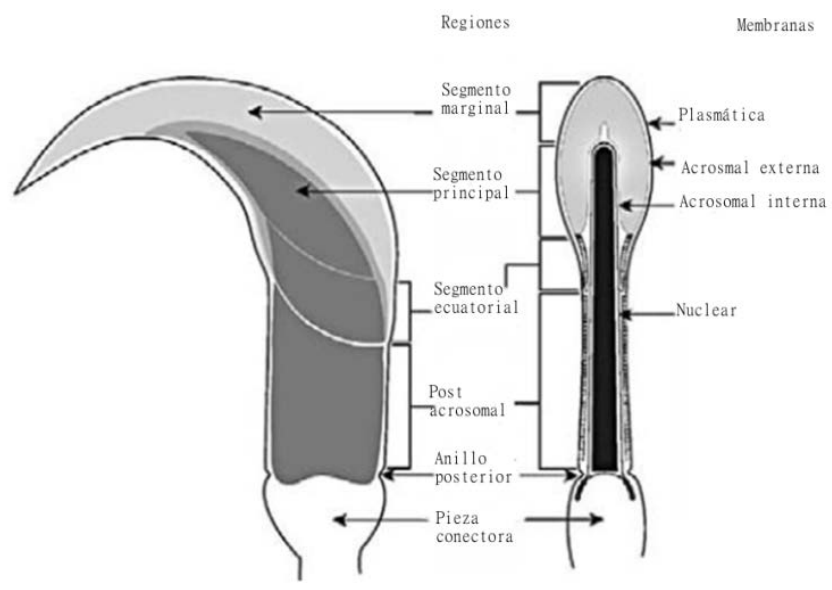

Figura 5. Distribución de las regiones y membranas de la cabeza del espermatozoide. Las regiones incluyen el segmento marginal y principal del acrosoma anterior, el segmento ecuatorial del acrosoma posterior, y la región postacrosomal entre el margen posterior del acrosoma y el anillo posterior. La membrana más externa envuleve al espermatozoide en su totalidad, mientras que la membrana acrosomal externa e interna forman una envoltura continua del contenido acrosomal. La envoltura nuclear es una doble membrana que envuelve al núcleo Modificado de Eddy, 2006.

La asociación entre las membranas y las estructuras internas forman barreras entre los dominios y sirven para restringir el movimiento de algunas proteínas. La membrana plasmática está asociada con la unión de la pieza media y la pieza principal, y con el anillo posterior en la unión entre la cabeza y la pieza conectora (Eddy, 2006).

La cromatina del espermatozoide es una estructura altamente organizada y compacta que mantiene la integridad genómica (Kort et al., 2006). En la región del cuello, hay una pequeña área de cromatina descondensada donde se lleva a cabo la transcripción, traducción y biosíntesis de proteínas (Pesch y Bergmann, 2006).

El flagelo es la parte más larga del espermatozide, y consiste de la pieza conectora, la pieza media, la pieza principal y la pieza final (Eddy, 2006; Sutovsky y Manandhar, 2006). En el flagelo se encuentra la maquinaria necesaria para que el espermatozoide se desplace a través del tracto reproductor femenino (Mortimer, 1997). El axonema, en mamíferos, se encuentra rodeado por nueve fibras densas externas y una envoltura fibrosa delgada presente en casi toda 
la longitud del flagelo (Tapia y Peña, 2009). La membrana del flagelo se divide en la pieza media, la pieza principal y la pieza distal (Eddy, 2006). Existe una correlación positiva entre la sobrevivencia del espermatozoide y el número de mitocondrias. Las mitocondrias proveen la energía (ATP) la cual es usada principalmente para la movilidad (Pesch y Bergmann, 2006).

La principal fuente de energía del espermatozoide es el trifosfato de adenosina(ATP), el cual es producido por la mitocondria de la pieza media y metabolizada por la ATPasa en el flagelo. La energía liberada causa contracción de los brazos de dineína e induce movimiento flagelar y la movilidad del espermatozoide (Comhaire, 1993).

La viabilidad y la movilidad del espermatozoide depende probablemente de factores que actúan durante la producción espermática y durante el tránsito a lo largos del epidídimo (Comhaire, 1993).

La función del espermatozoide es liberar su genoma haploide en el óvulo, y así combinarse con el genoma haploide femenino para iniciar el desarrollo de una nueva generación. La fertilización es el proceso por el cual interactúan el óvulo y el espermatozoide para lograr el reconocimiento y fusionarse para crear un cigoto, el cual se desarrolla para formar un nuevo individuo, lo que permite la continuidad de la especie (Okabe, 2013).

Los espermatozoides en la cauda del epidídimo aún no han completado el proceso de maduración funcional y están limitados en su capacidad funcional. La capacitación puede ser definida como aquellos eventos de maduración por los cuales el espermatozoide adquiere la capacidad de que el acrosoma reaccione en respuesta a las señales de la zona pelúcida del ovocito (Florman y Ducibella, 2006).

La capacitación está asociada con cambios en la fisiología y la bioquímica del espermatozoide como alteraciones en la superficie de la membrana citoplasmática, entre ellas, la composición en las proteínas de membrana, la localización de antígenos y los cambios en la carga de la superficie, los cambios en las propiedades de la membrana plasmática como el potencial de membrana, composición lipídica, la asimetría de los fosfolípidos transmembranales, la difusión lateral de lípidos y proteínas y cambios en la fosforilación de proteínas (Florman y 
Ducibella, 2006). Tales cambios permitirán que el espermatozoide llegue al sitio de fertilización e interactúe con el ovocito para cumplir su objetivo (Okabe, 2013). 


\section{ANTECEDENTES}

La apoptosis es una forma de muerte celular presente en las células somáticas y en las células germinales testiculares (Aragón y Becerril 2012). Se han identificado características típicas de apoptosis en los espermatozoides eyaculados de humano, cerdo, caballo, toro, ovinos, rata, hámster y ratón, como la fragmentación de ADN, formación de burbujas en la membrana plasmática, condensación de la cromatina, pérdida del potencial de la membrana mitocondrial, pérdida de la integridad de la membrana plasmática, externalización de la fosfatidilserina y activación de caspasas (Cisternas y Moreno 2006; Grunewald et al.,2006; Chaveiro et al.,2007; Ortega-Ferrusola et al.,2008; Pichardo et al., 2010; Morales et al., 2012; García et al., 2012).

Los espermatozoides eyaculados de ovino y de cerdo son células que pueden resultar positivas a marcadores de apoptosis, como la presencia de caspasas activas 3 y 7 (Pichardo et al, 2010; Morales et al., 2012, García et al., 2012). García et al (2012) demostraron la presencia de caspasas activas en espermatozoide de diferentes regiones del epidídimo sin encontrar diferencias entre los porcentajes de espermatozoides con caspasas activas del caput, el corpus y la cauda del epidídimo.

En los espermatozoides de humano se ha observado que en las células germinales apoptóticas la mitocondria se encuentra alargada y abultada comparada con la morfología mitocondrial normal de las células vecinas no apoptóticas (Erkkila et al.,1999), estas alteraciones mitocondriales observadas durante la apoptosis se han asociado con la infertilidad masculina (Marchetti et al., 2002). Se ha observado que la presencia de caspasas activas en espermatozoides eyaculados de humano está correlacionada con la fragmentación del ADN en pacientes infértiles y en fracciones con baja movilidad (Weng et al., 2002; Paasch et al., 2003). Por lo que es posible que el daño genético en espermatozoides, la apoptosis y la movilidad estén relacionados.

En el caso de los espermatozoides de roedores, se ha observado que presentan todos los componentes de la maquinaria apoptótica descrita en las células somáticas; sin embargo, no se sabe si la activación de las caspasas está relacionada con el proceso apoptótico o con un 
proceso similar (Cisternas y Moreno, 2006). Así mismo, se ha descrito la presencia de caspasas activas en espermatocitos durante la primera fase de la espermatogénesis (Moreno et al., 2006). Blanco-Rodriguez y Martínez-García (1999), demostraron que algunos marcadores apoptóticos están restringidos a un compartimiento citoplasmático y forman cuerpos residuales similares a cuerpos apoptóticos.

Sakkas et al (1999) proponen que la presencia de marcadores apoptóticos en espermatozoides eyaculados de humano, con parámetros espermáticos anormales, es indicador de un proceso de “apoptosis abortiva”, es decir, que los mecanismos apoptóticos no fueron completados durante la espermatogénesis; por lo que es posible que los espermatozoides acarreen caspasas en estado activo desde que abandonan el testículo (García et al., 2012).

Aunque la apoptosis representa el modo más estudiado de muerte celular, se ha visto que algunas caspasas tienen funciones distintas a las apoptóticas, por ejemplo, las caspasas efectoras junto con sus reguladores eliminan porciones de una célula, esculpiendo o alterando la citoarquitectura (Fuchs 2011).

Se sabe que la muerte celular ocurre de manera natural y continua durante la espermatogénesis, lo que resulta en la pérdida de más del $75 \%$ de las células que potencialmente podrían convertirse en espermatozoides (Huckins, 1978). La pérdida significativa de células germinales ocurre durante la fase de espermatogonias (proliferación), principalmente durante las divisiones mitóticas de las espermatogonias tipo $A_{2}$ a $A_{4}$, en donde participan proteínas proapoptóticas como la proteína p53, así como Bcl-2, Bax y Fas (Hess y Da Franca, 2008).

Sakkas et al. (2003) sugirió dos papeles para la apoptosis durante la espermatogénesis normal: 1) limitar la población de células germinales a un número que pueda ser soportada por las células de Sertoli y 2) una posible eliminación selectiva de los espermatozoides anormales.

Numerosos reportes han evidenciado el papel de la apoptosis en la regulación fisiológica y patológica de las células germinales masculinas (Tapia y Peña 2009). En el testículo la apoptosis involucra a las caspasas, a promotores de caspasas y adaptadores que regulan la 
muerte celular en al menos dos vías, ya sea por señales intracelulares que resultan en el daño al ADN (ruta intrínseca) o por una señal específica a través de receptores de muerte en la superficie celular (ruta extrínseca). Sin embargo, se ha sugerido que existe una ruta más, la ruta del retículo endoplásmico, la cual está involucrada en la muerte de células germinales testiculares en ratones hipogonadales deficientes de gonadotropinas, debido a la sobre expresión del ARNm de la caspasa 12 (Chausiax et al., 2008).

La apoptosis de las células germinales testiculares incrementa en respuesta a la estacionalidad y a la deprivación hormonal inducida, la temperatura elevada, la isquemia o los agentes tóxicos conocidos por suprimir la producción de espermatozoides y que actúan sobre los factores de sobrevivencia de las células germinales (Huhtaniemi y Bartke, 2001). Con respecto a este último punto, se ha observado que el establecimiento de la espermatogénesis es interrumpido por la administración de p-cloroanfetamina (pCA) a ratas prepúberes y adultas debido a eventos apoptóticos (Aragón et al., 2005).

Los factores reguladores apoptóticos, como Bax, Bcl-2, Fas/FasL y varias caspasas están involucrados en la eliminación de células espermatogénicas defectuosas mediante la apoptosis (Sutovsky y Manandhar, 2006). En los testículos de rata de 18 a 26 días de edad se ha observado un pico en la expresión de las proteínas proapoptóticas Bax y Bad, lo que sugiere que la ruta intrínseca es activada en la apoptosis fisiológica en los espermatocitos primarios en paquiteno, durante la primera ola de espermatogénesis (Moreno et al., 2006).

En las células somáticas después de los eventos moleculares, se presentan los cambios morfológicos; las células en proceso de muerte se encogen, se separan de las células vecinas y el núcleo comienza a condensarse. Una de las modificaciones tempranas de las células apoptóticas involucra la exposición de la PS hacia la cara externa de la membrana, estas células se unen a los receptores de los macrófagos, los cuales fagocitan los fragmentos celulares. Las células de Sertoli reconocen, fagocitan y remueven las células espermatogénicas que expresan PS (Ruwanpura et al., 2010).

Aunque el papel de la apoptosis durante la espermatogénesis y en células somáticas se ha descrito, existe controversia acerca de la importancia de un proceso apoptótico en el 
espermatozoide eyaculado. No es claro si los marcadores apoptóticos observados en espermatozoides eyaculados de mamíferos son residuos de un proceso apoptótico abortivo, iniciado antes de la eyaculación, o si son el resultado de apoptosis iniciada en el periodo posteyaculación. Independientemente del origen de los marcadores apoptóticos observados en el espermatozoide, su relación con la movilidad, capacitación, reacción acrosomal y otros parámetros relevantes, permanece aún en debate (Tapia y Peña 2009).

\section{Presencia de caspasas activas en espermatozoides}

Las causas de la presencia de marcadores apoptóticos en los espermatozoides eyaculados son controversiales. Se conocen dos interpretaciones que pretenden explicar la presencia de marcadores de apoptosis en los espermatozoides eyaculados. La primera es que durante la espermatogénesis las células germinales defectuosas son marcadas para su eliminación y comenzar la apoptosis, pero algunas de estas células escapan de la eliminación en el testículo y aparecen en el eyaculado como espermatozoides apoptóticos, también conocida como la teoría de la apoptosis abortiva, planteada por Sakkas et al.,1999. La segunda teoría es que un proceso apoptótico activo ocurre en el espermatozoide maduro (Tapia y Peña, 2009).

Con la finalidad de definir la presencia y papeles potenciales de los marcadores apoptóticos en el espermatozoide, Weng et al., (2002), identificaron la caspasa 3 activa e inactiva en la pieza media del espermatozoide eyaculado humano mediante inmunotinción. En espermatozoides de pacientes infértiles se detectó la presencia de diversas caspasas (Marchetti et al., 2004), mientras que las caspasas 3, 7 y 9 activas se observaron en subpoblaciones espermáticas con baja movilidad, lo que sugiere ser un indicativo de baja calidad espermática (Taylor et al., 2004).

Además de la movilidad, el estatus de maduración del espermatozoide también esta correlacionado con la presencia de caspasas activas, específicamente de las caspasas 3, 8 y 9 . Esta actividad está, a su vez, asociada con la disrupción del potencial de membrana mitocondrial en los espermatozoides inmaduros (Paasch et al., 2003). 
Una de las características en el espermatozoide humano, la cual define el control de la apoptosis en este tipo celular, es su alto nivel de compartimentalización. El espermatozoide presenta una arquitectura única con la mitocondria y el citoplasma en un compartimento subcelular distinto al del núcleo. La cromatina está altamente condensada que llega al límite físico de compactación, como resultado el ADN existe en un estado semi-cristalino (Aitken y Baker 2013).

De manera tradicional, la calidad espermática es evaluada mediante un análisis de semen estándar donde se determina la concentración, la movilidad y morfología; sin embargo, debido a la subjetividad de estos parámetros, son necesarios métodos más confiables. La fragmentación de $\mathrm{ADN}$, la producción de especies reactivas de oxígeno (ROS), el potencial de membrana mitocondrial y la presencia de caspasas activas son unas de las pruebas más sensibles para determinar la calidad espermática (Marchetti y Marchetti 2007).

\section{Inducción de caspasas activas en espermatozoides}

Se sabe que en los espermatozoides se pueden detectar marcadores de apoptosis mediante la inducción de la apoptosis o de un proceso similar por una variedad de estímulos y estresores como el calor, el proceso de criopreservación, la adición de substancias como la progesterona, la estaurosporina, el ácido betulínico, el nitroprósido de sodio, el peróxido de hidrógeno, el imiquimod y el factor de necrosis tumoral- alfa (TNFa) (Brum et al., 2008; Bejarano et al., 2008; Pichardo et al., 2010; García et al., 2012; Huang et al., 2012).

Los indicadores de apoptosis que han sido observados en los espermatozoides de cerdos y ovinos son la presencia de caspasas activas, la pérdida del potencial de membrana mitocondrial, la externalización de la fosfatidilserina y la fragmentación del ADN (Tapia y Peña, 2009; García et al., 2012; Morales et al., 2010).

El imiquimod es un componente sintético que pertenece a la familia de las imidazoquinolinas, que tiene una masa molecular relativa de 240.3g/mol. El Imiquimod es utilizado como un método terapéutico no invasivo en el tratamiento clínico del cáncer. Se ha reportado, además, 
que ejerce actividad directa pro-apoptótica contra varias poblaciones de células tumorales in vitro e in vivo (Huang et al., 2012).

Se han descrito tres hipótesis respecto a los mecanismos moleculares involucrados en la apoptosis inducida por imiquimod. La primera es que el imiquimod puede actuar directamente sobre los receptores de muerte unidos a la membrana celular, lo que inicia la cascada apoptótica de transducción de señales por uno o más de estos receptores. La segunda, es que el imiquimod puede afectar a las moléculas unidas a los receptores de muerte, provocando la activación de caspasas y la subsecuente muerte celular, pasando por alto los receptores unidos a la membrana plasmática. Por último, el imiquimod puede influir en la liberación del citocromo c mitocondrial dependiente de Bcl-2, llevando a la activación de la caspasa 9 y como consecuencia a la muerte celular (Schön et al., 2003).

Huang et al (2012) demostraron que en células de cáncer de piel, el imiquimod induce apoptosis mediante la vía intrínseca y disminuye los niveles de la proteína Mcl-1, una proteína anti-apoptótica.

\section{Citometría de flujo}

La citometría de flujo, es un método analítico que permite medir características celulares en un sistema de flujo. La citometría de flujo permite evaluar diferentes características del espermatozoide tales como la estructura de la cromatina, la viabilidad espermática, la función mitocondrial, el estatus acrosomal y defectos espermatogénicos (Perticarari et al.,2007; Levek-Motola et al., 2005; Garner et al., 1997).

La citometría de flujo es un método multiparamétrico que ofrece la posibilidad de una evaluación simultánea, simple, rápida, reproducible y adecuada de varios parámetros del semen. Cientos de células pueden ser analizadas en pocos segundos, lo cual proporciona una evaluación estadísticamente más precisa (Perticarari et al., 2007).

Las propiedades celulares medidas en el citómetro se basan en dos principios: la dispersión de la luz y la fluorescencia. La luz no se dispersa igual en todas las direcciones y la mayoría se proyecta hacia adelante. La luz dispersada hacia adelante (“forward scatter”, FSC) es una 
medición del tamaño celular, mientras que la luz dispersada en ángulo recto (“side scatter”, SSC) depende de la densidad celular y de la granulosidad y brinda una idea de la “complejidad” celular (Evenson et al., 2002).

Las células deben encontrarse en suspensión para permitir el análisis de manera individual. Esto significa que miles de células pueden ser analizadas y la información estadística de grandes poblaciones celulares es obtenida en periodos de tiempo cortos. Así mismo, las células deben ser marcadas con moléculas fluorescentes (fluorocromos) capaces de excitarse con una fuente luminosa de alta energía (Givan, 2011).

Las posibilidades analíticas de esta técnica se han incrementado con el desarrollo de un amplio número de fluorocromos que se unen de manera específica a moléculas, se acumulan en compartimentos celulares o modifican sus propiedades a través de reacciones bioquímicas específicas. La posibilidad de combinar diferentes moléculas fluorescentes permite realizar un análisis simultáneo de diferentes parámetros, lo cual supone una ventaja frente a otros sistemas de análisis celular. Los fluorocromos usados para teñir a las células deben ser capaces de absorber longitudes de onda particulares de la luz y los detectores deben tener los filtros apropiados para detectar la fluorescencia emitida (Givan 2011).

Un citómetro de flujo consta de tres componentes generales, el sistema de fluidos, al sistema de excitación y detección y el sistema de análisis. Los dos primeros componentes conforman la parte electrónica y de mecánica de fluidos, mientras que el tercero se refiere al software de captura. Los citómetros de flujo son equipos grandes y sensibles cuyo manejo mediante software se ha tornado muy sofisticado (Figura 6). 


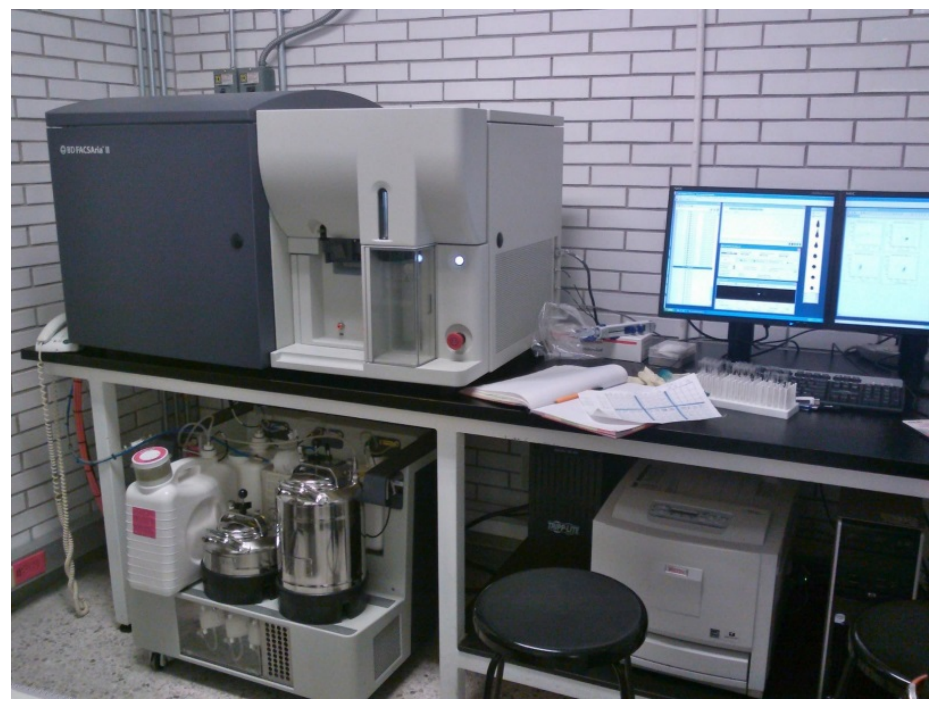

Figura 6. Citómetro de flujo. El citómetro de flujo permite analizar miles de células en suspensión en poco tiempo. Las células deben ser marcadas con moléculas fluorescentes.

Los métodos citométricos de apoptosis proporcionan un estimado del porcentaje o fracción de células apoptóticas en un momento en particular. La apoptosis es un evento transitorio y cinético (Smolewski et al., 2002), que puede ser evaluado mediante citometría de flujo.

El inhibidor fluorescente de caspasas (FLICA) es usado para detener la progresión de la apoptosis en las células y prevenir la desintegración y pérdida celular. Debido a que las células apoptóticas son marcadas mediante un fluorocromo, son fácilmente identificadas mediante microscopía de fluorescencia o citometría de flujo (Smolewski et al., 2002). FLICA contiene una secuencia peptídica inhibidora, una fluorometilcetona (FMK), que se une de forma covalente e irreversible al sitio activo de la caspasa, y un reportero fluorescente (fluoresceína), lo que hace posible cuantificar el número de células apoptóticas (Darzynkiewicz et al., 2011).

La tinción de espermatozoides con FLICA ha sido utilizada para detectar caspasas activas. Este ensayo puede ayudar a evaluar la apoptosis y su papel en la fertilidad masculina (Brugnon et al., 2007). Los procedimientos de citometría de flujo para espermatozoides han sido desarrollados para evaluar la viabilidad, la integridad acrosomal y la función mitocondrial. Para el análisis de espermatozoides viables, las células son definidas como aquellas que poseen una membrana plasmática intacta. Este atributo es evaluado mediante la 
tinción de una muestra espermática con ioduro de propidio (IP), una molécula fluorescente que se une al ADN. Las células que poseen daño en la membrana permitirán la entrada del IP a la célula y se unirá al ADN lo que causa la fluorescencia roja en las células (Graham 2001).

\section{Inmunocitoquímica}

La inmunocitoquímica es una técnica utilizada para la identificación de un componente celular in situ mediante la interacción específica antígeno-anticuerpo donde el anticuerpo ha sido marcado con un marcador visible. El marcaje celular es un método poderoso para demostrar la presencia y localización subcelular de una molécula en particular (Mao et al., 1994).

En los espermatozoides eyaculados de humano es útil el inmunomarcaje para detectar la presencia de proteínas involucradas en el proceso apoptótico, como las caspasas activas, PARP y sus homólogos (Celik-Ozenci y Tasatargil, 2013).

\section{La rata como modelo animal}

La rata se ha utilizado en el laboratorio como un modelo animal conocido y de fácil manejo; lo anterior ha permitido estudiar sus características biológicas y los mecanismos de diversas enfermedades con el objetivo de entender las rutas normales de dichas enfermedades, e identificar variantes genéticas que la conducen. La rata es usada en estudios de laboratorio, principalmente debido a su tamaño, conducta, biología y el costo para su mantenimiento en comparación con animales más grandes, incluidos los primates (Dwinell et al., 2011).

El uso de la rata como modelo para la investigación biomédica está en crecimiento debido a la disponibilidad de tecnologías genéticas y la riqueza de los datos fenotípicos (Dwinell et al., 2011). La importancia histórica de esta especie para la investigación se ve reflejada en la cantidad de literatura sobre la misma.

Se han creado diversas cepas o líneas para experimentación, entre ellas la cepa CII-ZV, la cual fue utilizada en el presente trabajo. 


\section{PLANTEAMIENTO DEL PROBLEMA}

En los espermatozoides de humanos, de especies de interés pecuario y en roedores, se ha descrito la presencia de caspasas activas. En algunos trabajos, la presencia de caspasas activas en los espermatozoides se ha relacionado con problemas de fertilidad.

Actualmente, diferentes grupos de trabajo alrededor del mundo investigan distintos marcadores apoptóticos en el espermatozoide, con el objetivo de predecir con éxito el potencial fertilizante de dicho gameto; en el caso de las caspasas activas, sin embargo, se desconoce si llevan a cabo una actividad proteolítica que lleve a la pérdida de función celular. A la fecha se desconoce el rol biológico de las caspasas activas en los espermatozoides.

\section{JUSTIFICACIÓN}

Algunas características apoptóticas presentes en células somáticas se han descrito en los espermatozoides de diferentes especies, tal es el caso de las caspasas activas. Aunque se desconoce el papel de las caspasas en los espermatozoides, su presencia se ha relacionado con problemas de fertilidad. Debido a que los espermatozoides no mueren por apoptosis, cabe la posibilidad de que las caspasas activas tengan un papel no apoptótico en los espermatozoides.

La apoptosis en las células somáticas y en las células germinales testiculares está bien establecida; sin embargo, las causas de la presencia y el significado de las caspasas en los espermatozoides eyaculados permanecen sin resolver. No es claro si la presencia de las caspasas activas en los espermatozoides eyaculados sean resultado de un proceso apoptótico abortivo, iniciado antes de la eyaculación, o si resulta de la apoptosis iniciada después de la eyaculación.

Aunque se sabe que las caspasas dividen diferentes substratos simultáneamente para dar inicio a la cascada apoptótica, solo se ha reportado la división de PARP por la caspasa 3 en espermatozoides eyaculados de humano. La detección de la división de los sustratos de caspasas es un marcador molecular para la evaluación de la apoptosis. 
Los espermatozoides de mamíferos no experimentan un proceso apoptótico como se ha descrito para las células somáticas debido a su particular morfología y composición celular a pesar de presentar todos los componentes de la maquinaria apoptótica. Hasta la fecha, no hay estudios que describan el papel de las caspasas activas en los espermatozoides.

\section{OBJETIVO GENERAL}

Detectar la presencia de las caspasas 3 y 7 activas, y de algunos de sus substratos divididos, en los diferentes tipos de células germinales masculinas.

\section{OBJETIVOS PARTICULARES}

1. Evaluar mediante citometría de flujo la expresión de las caspasas activas 3 y 7 marcadas con un inhibidor fluorescente, en espermatozoides de conductos deferentes sometidos a la inducción química de caspasas activas.

2. Detectar mediante inmunocitoquímica a la caspasa 3 y a los substrratos divididos alfa fodrina y PARP en espermatozoides de conductos deferentes sometidos a la inducción química de caspasas activas.

3. Detectar mediante inmunohistoquímica a la caspasa 3 y a los substratos divididos alfa fodrina y PARP en células germinales testiculares de ratas, a las cuales se les haya inducido apoptosis de las células germinales mediante la administración de pCA.

\section{MATERIAL Y MÉTODOS}

\section{Obtención de muestras espermáticas}

Los experimentos se llevaron a cabo en el Laboratorio de Pubertad de la Unidad de Investigación Multidisciplinaria de la FES-Zaragoza de la UNAM y en el Laboratorio de Fisiología de la Reproducción, laboratorio R-016 de la UAM-Iztapalapa. 
Se emplearon siete ratas machos adultos de la cepa CII-ZV de 90 días de edad, con un peso corporal entre 400-450 g mantenidas en condiciones controladas de luz-obscuridad, temperatura y con libre acceso al agua y al alimento, las cuales fueron mantenidas en el bioterio de la Facultad de Estudios Superiores-Zaragoza (FES-Zaragoza) de la UNAM. Las ratas fueron anestesiadas dentro de una cámara con éter durante 10-15 min y sacrificadas para obtener muestras espermáticas de los conductos deferentes. Los espermatozoides se colocaron en un tubo cónico para microcentrífuga con $800 \mu \mathrm{l}$ de solución Tyrodes (Sigma St. Louis, MO, U.S.A), y se mantuvieron a $37^{\circ} \mathrm{C}$ en un baño seco hasta su análisis.

\section{Activación de caspasas}

Para inducir la activación de novo de las caspasas en los espermatozoides, de cada suspensión espermática se tomó una alícuota de $100 \mu \mathrm{l}$ y se incubaron con $4 \mu \mathrm{l}$ de Imiquimod (Sigma St. Louis, MO, U.S.A) durante 30 minutos.

\section{Detección de caspasas activas 3 y 7}

Una alícuota de las muestras espermáticas se incubó durante 45 minutos con $0.5 \mu \mathrm{l}$ del reactivo SR-DEVD-FMK contenido en el kit Image-iT Red caspase -3 and -7 (Molecular Probes Inc. Eugene, OR, USA) en adelante nombrado como FLICA, para la detección de caspasas activas 3 y 7 in situ. FLICA es un inhibidor específico de las caspasas 3 y 7 que fluoresce al asociarse de manera covalente mediante una fluorometilcetona a la parte activa de las caspasas. El inhibidor fue usado con los controles apropiados de acuerdo a las instrucciones del fabricante. Como contratinción el ioduro de propidio para evaluar viabilidad ( $0.5 \mu \mathrm{l}$ de yoduro de propidio, durante $5 \min$ a $37^{\circ} \mathrm{C}$ ).

Para demostrar la especificidad de FLICA, se evaluó la ausencia de fluorescencia en las muestras de semen antes de la adición de FLICA (control). Las caspasas endógenas fueron bloqueadas agregando Z-DEVD-FMK (Sigma St. Louis, MO, USA), un inhibidor permeable a la célula de caspasas 3, 6, 7, 8 y 10. 
Antes de evaluar la expresión de caspasas activas por citometría de flujo, el volumen de cada muestra fue ajustado a $300 \mu \mathrm{l}$ con FACS Flow (Becton Dickinson, Immunocytometry Systems, San Jose, CA, USA), con la finalidad de que las células se encuentren en suspensión.

Se utilizó un citómetro de flujo FACSAria II (Becton Dickinson, Immunocytometry Systems, San Jose, CA, USA) equipado con un láser argón (488 nm), se evaluaron 10,000 eventos por cada muestra espermática. Los eventos fueron capturados en el software BD FACSDiva, versión 6.1.2. 2008. El citómetro de flujo se encuentra ubicado en la Unidad de Investigación Multidisciplinaria de la FES-Zaragoza, UNAM, en el área de citometría de flujo.

Los porcentajes de espermatozoides positivos a caspasas fueron obtenidos con ayuda del Software WinList versión 3.0 (Verity Software House, Inc., Charlestown, MA, USA) en un PC con Windows XP.

\section{Detección y cuantificación de los substratos divididos de caspasas}

\section{Inmunocitoquímica}

La detección in situ de los substratos divididos por las caspasas 3 y 7 fue evaluada mediante inmunocitoquímica, utilizando un anticuerpo primario anti alfa-fodrina (GeneTex, GTX62082, Lometa, TX. U.S.A), anti-PARP (GeneTex, GTX61029, Lometa, TX. U.S.A), anti caspasa-3 (GeneTex, GTX22302, Lometa, TX. USA) y anti $\beta$-actina conjugado con biotina (Cell Signaling, 5057). Una alícuota de cada muestra espermática se colocó en una laminilla cargada con poly-L-lisina, se fijaron con formaldehído al $10 \%$, posteriormente se lavaron con PBS e incubaron con albúmina de suero al 5\% durante 30 minutos a $4{ }^{\circ} \mathrm{C}$ para bloquear sitios de unión no específicos.

La permeabilización se llevó a cabo mediante el uso de la solución Rodent Decloaker (Biocare Medical, RD913, Concord, CA, USA) durante 1 hora a $90^{\circ} \mathrm{C}$. La incubación con el anticuerpo primario, diluido en PBS, se llevó a cabo durante toda la noche (16 h). Posteriormente se lavaron las laminillas con PBS y se incubaron con la solución Rodent Polymer (Biocare Medical, RMR625, Concord, CA, USA) y el cromógeno Warp Chromogen (Biocare Medical, WR806, Concord, CA, USA) para llevar a cabo el revelado de la inmunotinción, excepto en 
las laminillas incubadas con biotina. En las laminillas control se omitió la incubación con el anticuerpo primario.

Las muestras se montaron con el medio de montaje Fluoro Care AntiFade Mountant (Biocare Medical, FP001, Concord, CA, USA) y se cubrieron con un cubreobjetos. Se sellaron con barniz. Las muestras se evaluaron en un microscopio de fluorescencia Eclipse E400 (Nikon Instruments, Melville, Nueva York).

\section{Inmunohistoquímica}

Con la finalidad de corroborar la funcionalidad de los anticuerpos se llevó a cabo la detección de los substratos divididos por las caspasas 3 y 7 en tejido testicular de ratas tratadas con pCA. Figura 7.

Se utilizaron cortes histológicos de testículos de ratas (4) tratadas con pCA (10 mg/kg de peso corporal), sacrificadas como se describió previamente, 24 horas después del tratamiento. Se tomaron 10 cortes por rata.

Las muestras histológicas testiculares fueron colocadas en laminillas cargadas con poly-Llisina. Se llevó a cabo el mismo procedimiento que en la inmunocitoquímica. En las laminillas control se omitió la incubación con el anticuerpo primario.

\section{Análisis en microscopía de fluorescencia}

Con la finalidad de corroborar la localización de las caspasas activas en los espermatozoides y para identificar la localización de las proteínas detectadas mediante inmunohistoquímica; las células así como el tejido testicular fueron examinados en un microscopio de fluorescencia Eclipse E400 (Nikon Instruments, Melville, Nueva York).

\section{Análisis en microscopía confocal}

Para identificar la localización de las proteínas detectadas mediante inmunohistoquímica, el tejido testicular fue examinado en un microscopio confocal LSMT-PMT (Zeiss) y se obtuvieron imágenes del marcaje obtenido. Se utilizó el software ImageJ 1.47f (Rasband, 
2005) para descomponer las imágenes lsm en sus diferentes canales y para hacer la sobreposición de los mismos.

\section{DISEÑO EXPERIMENTAL}

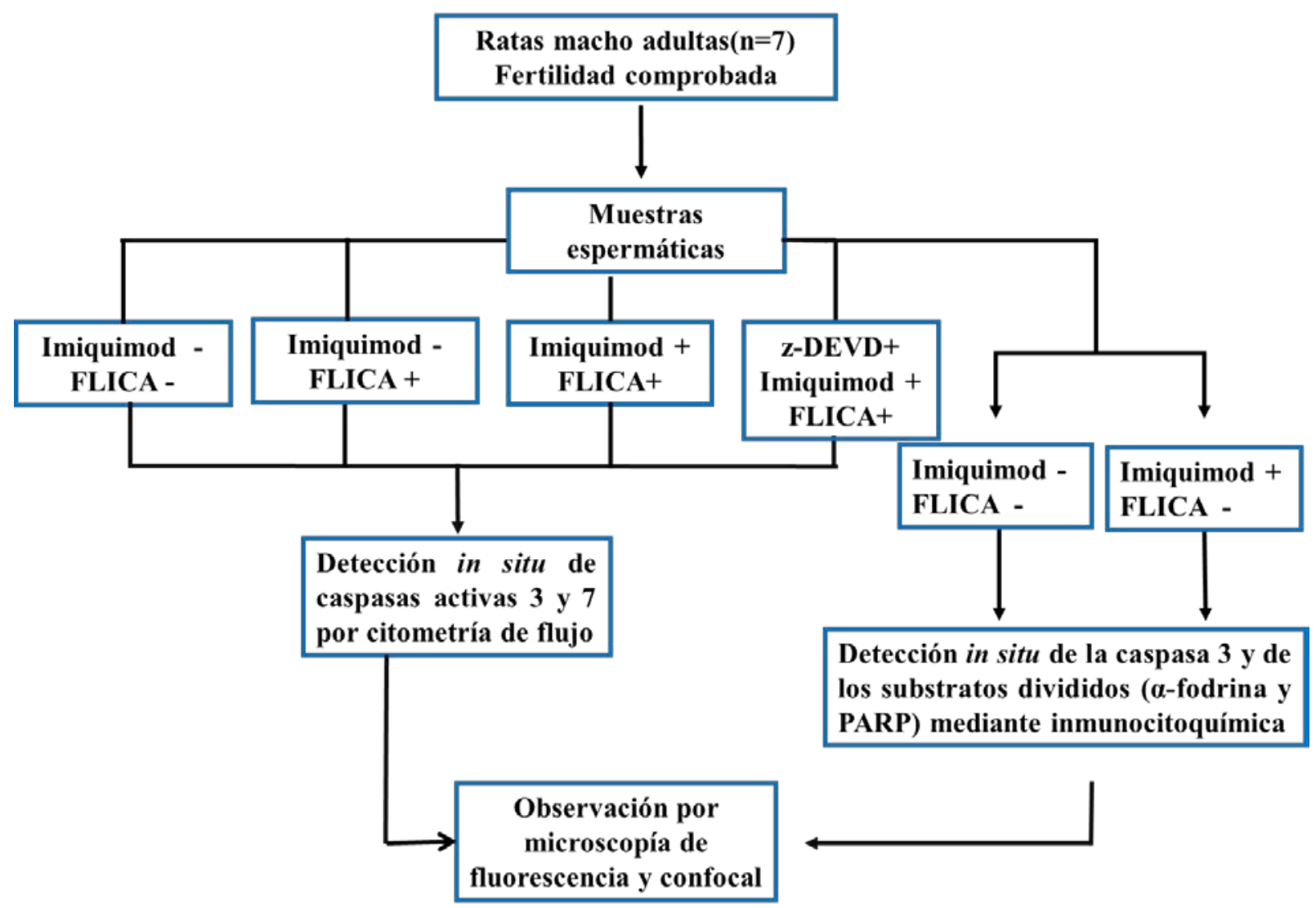

Figura 7. Diagrama del diseño experimental llevado a cabo en los espermatozoides de rata. 


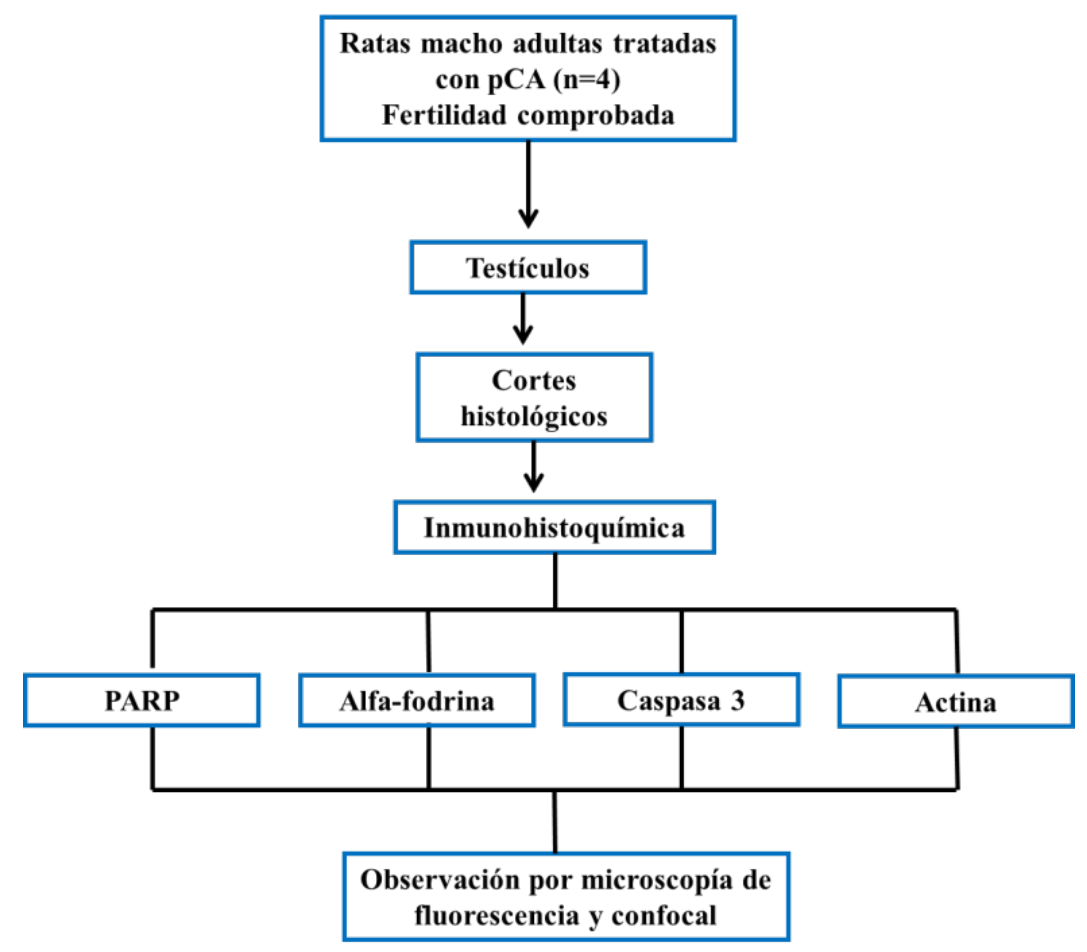

Figura 8. Diagrama del diseño experimental llevado a cabo en tejido testicular de ratas tratadas con pCA.

\section{ESTADÍSTICA}

Los porcentajes de espermatozoides con expresión de caspasas activas, en los diferentes tratamientos, se analizaron mediante un análisis de varianza de una vía, en donde se consideró al tratamiento como factor. Tukey se utilizó como prueba post hoc. Los resultados fueron considerados significativos cuando $\mathrm{p}<0.05$. Los resultados se expresan como como medias \pm DE. Todos los análisis se realizaron con el software R 2.9.0. en un macbook con MacOSX 10.8.4. 


\section{RESULTADOS}

\section{Expresión de caspasas activas 3 y 7}

El inhibidor fluorescente de caspasas (FLICA), fue utilizado para evaluar la presencia de caspasas 3 y 7 activas en espermatozoides de rata en alícuotas control de muestras espermáticas y en alícuotas incubadas con los diferentes tratamientos (Figura. 9).

La alícuota control, la cual no fue marcada con ningún fluorocromo, no presenta fluorescencia y corresponde al 100\% de la población celular. Cuando ésta misma alícuota se incubó con el reactivo FLICA para marcar los espermatozoides que expresaron caspasas activas, el porcentaje fue de $62.76 \%$.

Después de inducir la activación de caspasas mediante la incubación con imiquimod, el porcentaje de espermatozoides que expresan caspasas activas aumentó hasta 96.7\%, lo que indica que el inductor efectivamente está llevando a cabo la activación de caspasas en los espermatozoides. Al incubar las muestras con un inhibidor no fluorescente de caspasas activas más el inductor y posteriormente marcar los espermatozoides con FLICA, observamos una disminución en el porcentaje de espermatozoides que expresan caspasas activas (90.9\%). 


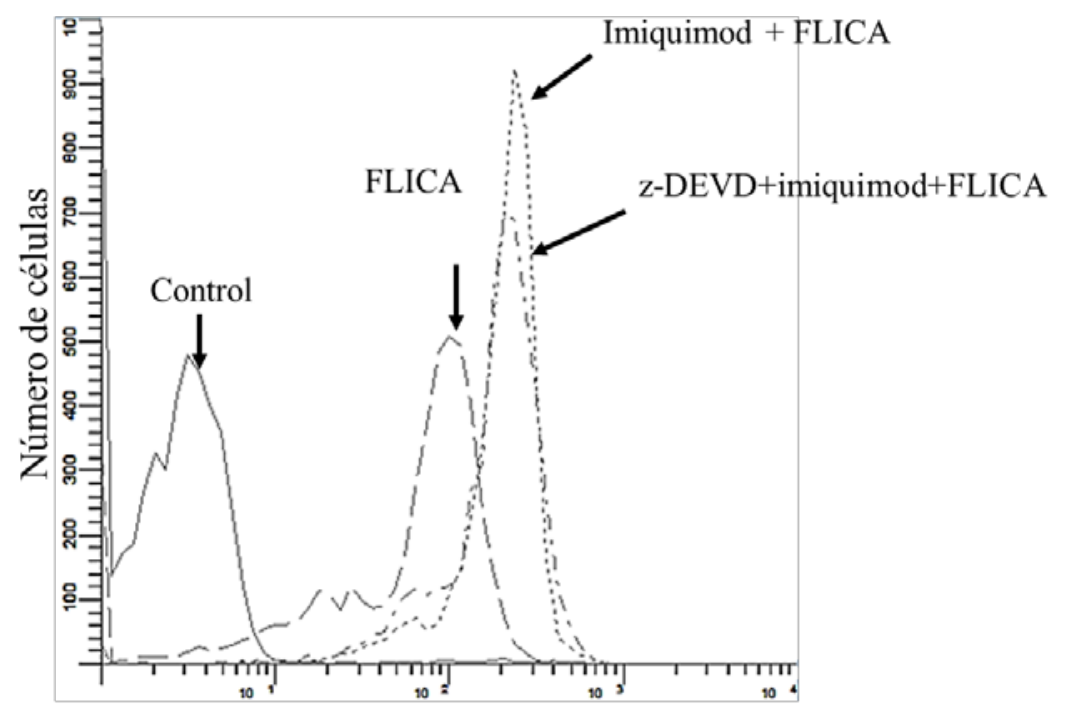

FLICA

Figura 9. Histogramas representativos del porcentaje de espermatozoides que expresan caspasas 3 y 7 activas en la muestra control (sin FLICA), en la muestra incubada con FLICA, en la muestra incubada con FLICA +Imiquimod y en las muestras con el inhibidor no fluorescente (z-DEVD).

En un análisis biparamétrico (FLICA+IP), se observa la presencia de distintas subpoblaciones espermáticas, células sin caspasas activas y sin daño en la membrana plasmática (FLICA-/IP); células sin caspasas activas y con daño en la membrana plasmática (FLICA-/IP+); células con caspasas activas y sin daño en la membrana plasmática (FLICA+/IP-); células con caspasas activas y con daño en la membrana plasmática (FLICA+/IP+), subpoblaciones representadas de color negro, rojo, verde y amarillo, respectivamente. (Figura 10).

En la figura 10-A se muestra un citograma representativo de una muestra control (sin fluorocromos), en donde cada punto corresponde a una célula. No hay subpoblaciones que presenten fluorescencia correspondiente a FLICA o a IP, es decir, no hay células positivas a caspasas 3 y 7 ni células positivas a IP, en la figura están representadas por la subpoblación en color negro

En cambio, en la figura 10-B se observa un citograma representativo de una muestra incubada con FLICA+IP. Se observan las cuatro subpoblaciones espermáticas descritas anteriormente. 
A

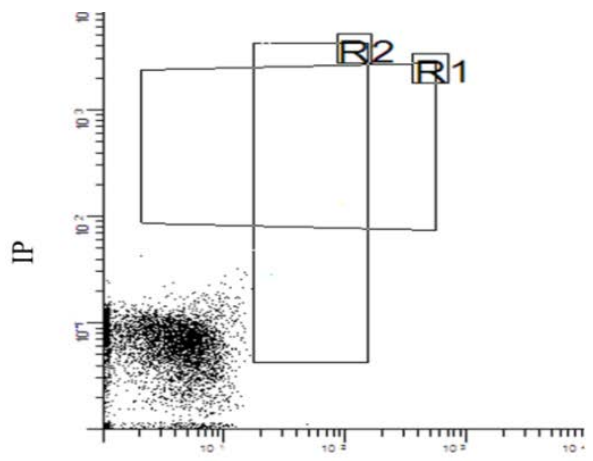

B

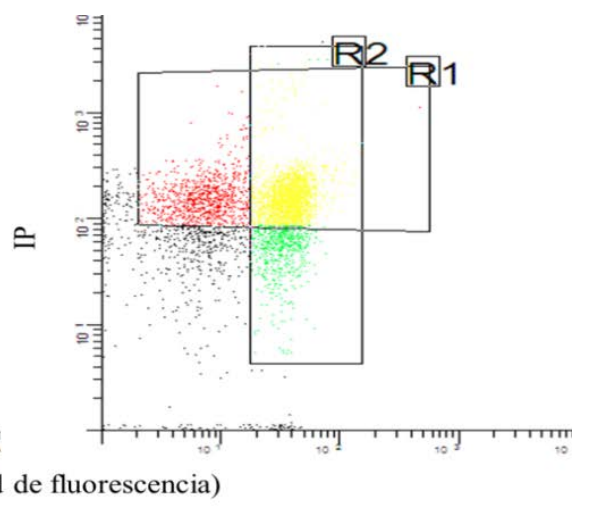

Figura 10. Identificación de diferentes subpoblaciones espermáticas en una muestra control (A) y en una muestra tratada con FLICA/IP. Se observan cuatro subpoblaciones espermáticas.

En un análisis cuantitativo de los datos obtenidos de citometría de flujo, se observaron diferencias significativas en el porcentaje de espermatozoides que expresan caspasas activas después de la inducción química con imiquimod comparado con el porcentaje de espermatozoides marcados solo con FLICA (62.7 \pm 2.99 vs $96.7 \pm 1.71)$. La inhibición con el marcador no fluorescente no disminuyó el porcentaje de células positivas a FLICA de manera significativa (Figura 11).

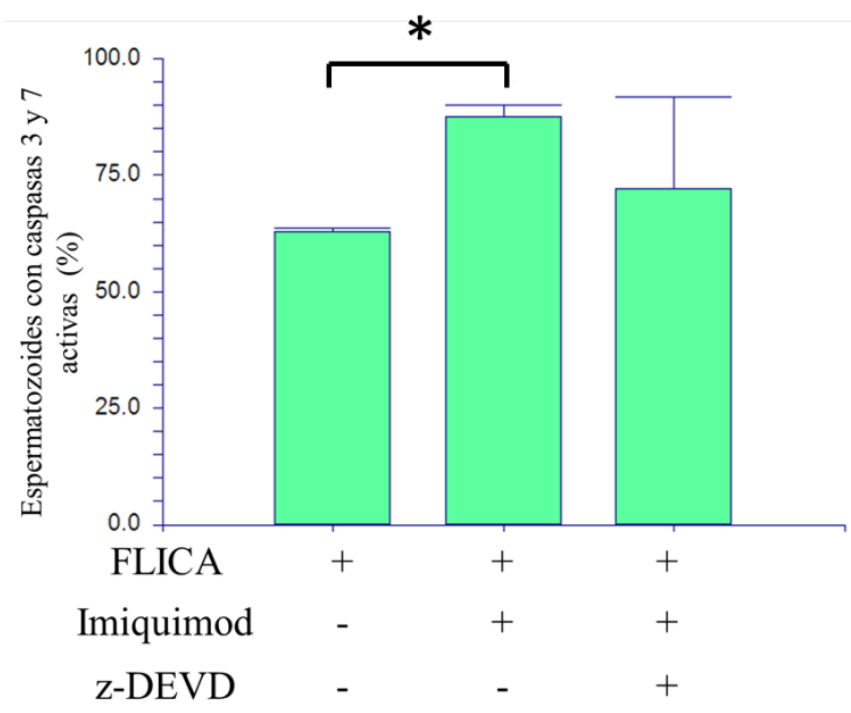

Figura 11. Efecto de la inducción o inhibición química, sobre la expresión de caspasas activas, en los espermatozoides de rata. El asterisco indica que existen diferencias significativas, $\mathrm{p}<0.05$. 
Mediante microscopia de fluorescencia se corroboró la presencia y localización de caspasas activas en los espermatozoides de rata (Fig. 12). Observándose una mayor intensidad de fluorescencia en la pieza media y principal del flagelo del espermatozoide de rata.

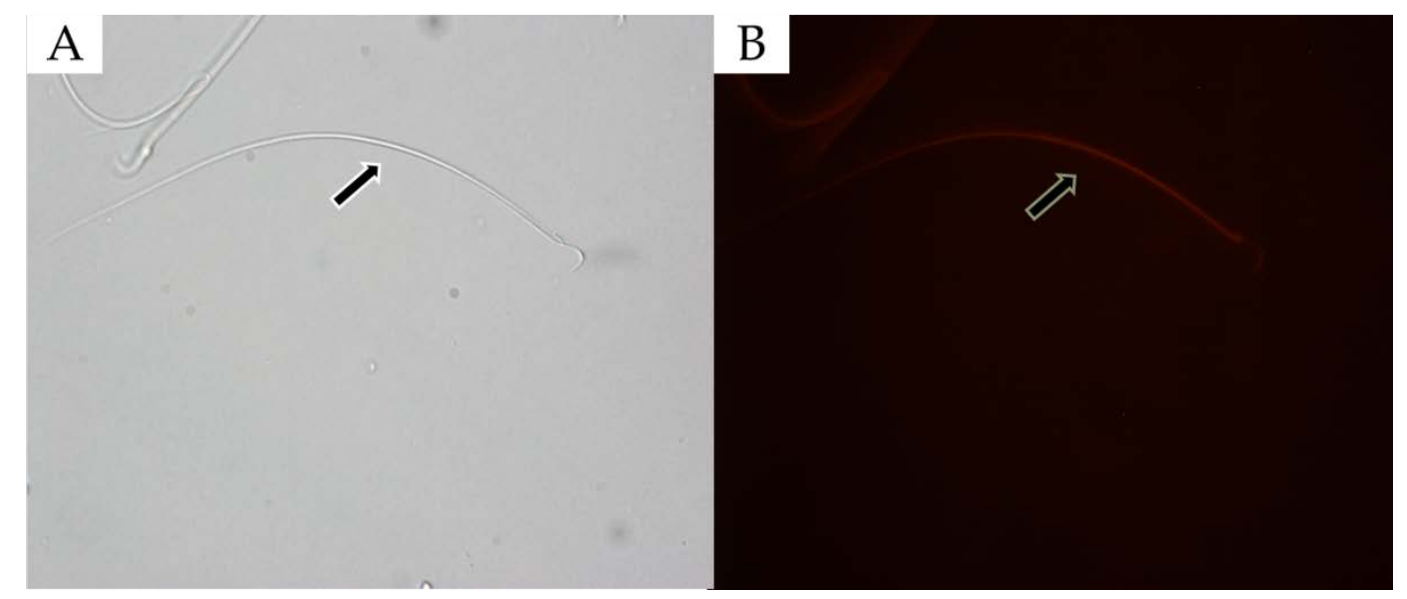

Figura 12. Localización de caspasas activas 3 y 7 en espermatozoides de rata, marcadas con FLICA, mediante microscopía de fluorescencia. A) Campo claro. B) Espermatozoide con presencia de caspasas activas. Fotografías tomadas con un aumento de 400X.

\section{Inmunohistoquímica}

Para determinar la presencia y localización de los fragmentos divididos de las proteínas alfafodrina y PARP y de caspasa 3 en los espermatozoides de rata, se realizó un análisis de inmunocitoquímica.

Los resultaron fueron negativos en cuanto a la detección de los fragmentos divididos de las proteínas alfa-fodrina, PARP y de caspasa 3 en los espermatozoides de rata. Por lo tanto, se prosiguió a la detección de las mismas proteínas en tejido testicular de ratas tratadas con pCA, un modelo de inducción de apoptosis en células germinales de rata (Aragón et al., 2005), y en los cuales si se encontró marcaje positivo a los anticuerpos antes mencionados. 

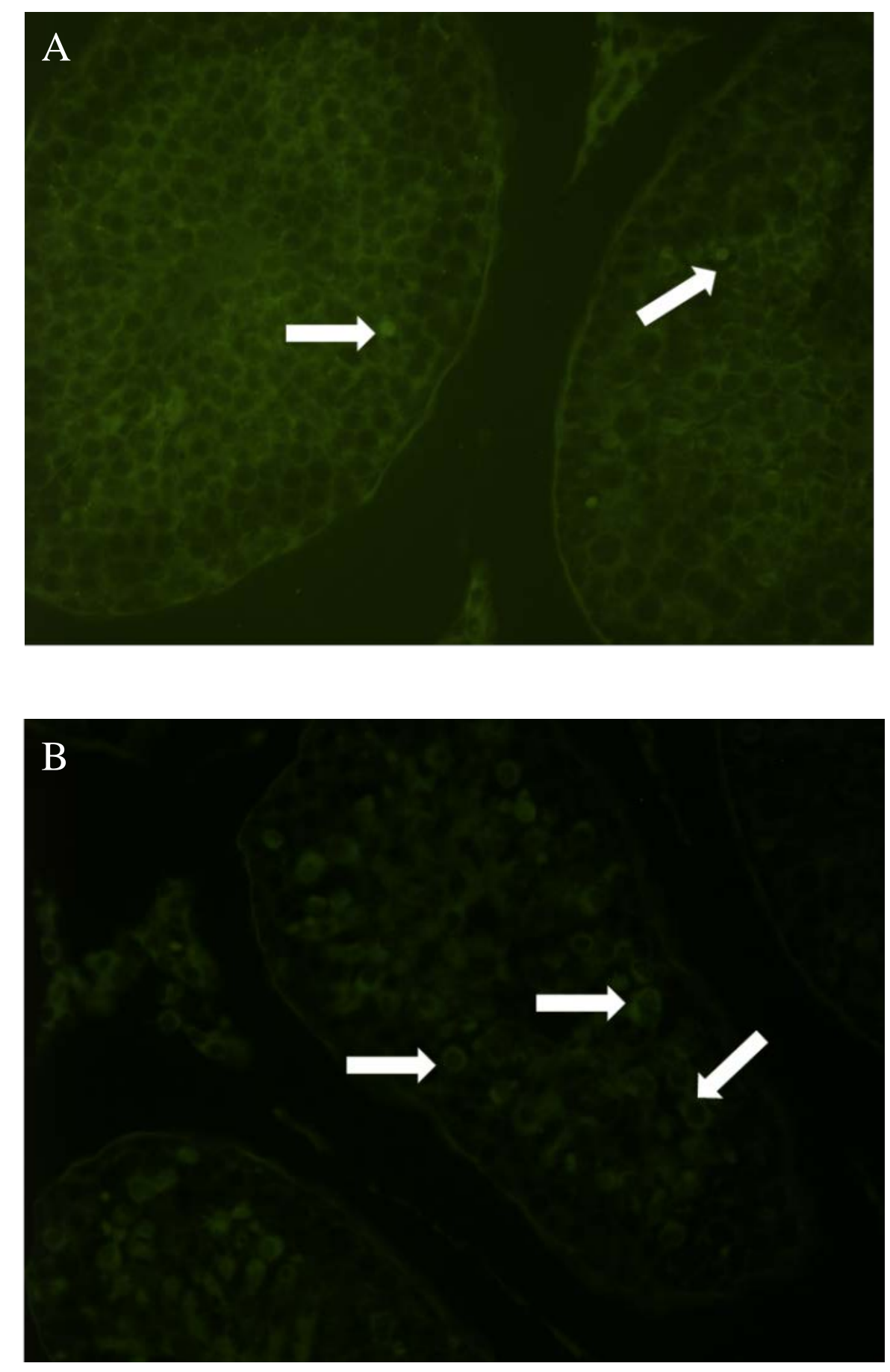

Figura 13. Inmunolocalización de las proteínas PARP (A) y caspasa 3 (B) en tejido testicular. Las flechas indican las células que resultaron positivas a los anticuerpos. Microfotografías tomadas a 40X. 
En la figura 13-A observamos la micrografía de un túbulo seminífero en donde las células marcadas con fluorescencia verde son aquellas que resultaron positivas al anticuerpo antiPARP. Su localización se encuentra en el centro (núcleo) de la célula, lugar donde se ha reportado la localización de PARP, ya que es una proteína involucrada en la reparación del ADN. En la figura 13-B se observan las células que resultaron positivas al anticuerpo anticaspasa 3. El marcaje se encuentra en la periferia de la célula (citoplasma). Las caspasas tanto en su forma inactiva o activa están localizadas en el citoplasma o en diferentes organelos citoplásmicos.

Posteriormente, se obtuvieron imágenes en un microscopio confocal de la detección de actina, utilizado como control, de caspasa 3, de los fragmentos divididos de las proteínas PARP y alfa-fodrina.

Las imágenes obtenidas mediante microscopía confocal fueron procesadas digitalmente para separar la fluorescencia roja, verde, azul y la sobreposición de las tres anteriores con la finalidad de distinguir las estructuras y el marcaje positivo a los anticuerpos utilizados.

En la figura 14, se observa la detección de actina en túbulos seminíferos, se marcaron los núcleos con IP (A), la detección de actina en los diferentes tipos celulares testiculares, observada en la región citoplásmica de las células. El software nos permite observar la sobreposición de las imágenes en donde se encuentra el marcaje de los núcleos (rojo) y de actina (verde). 

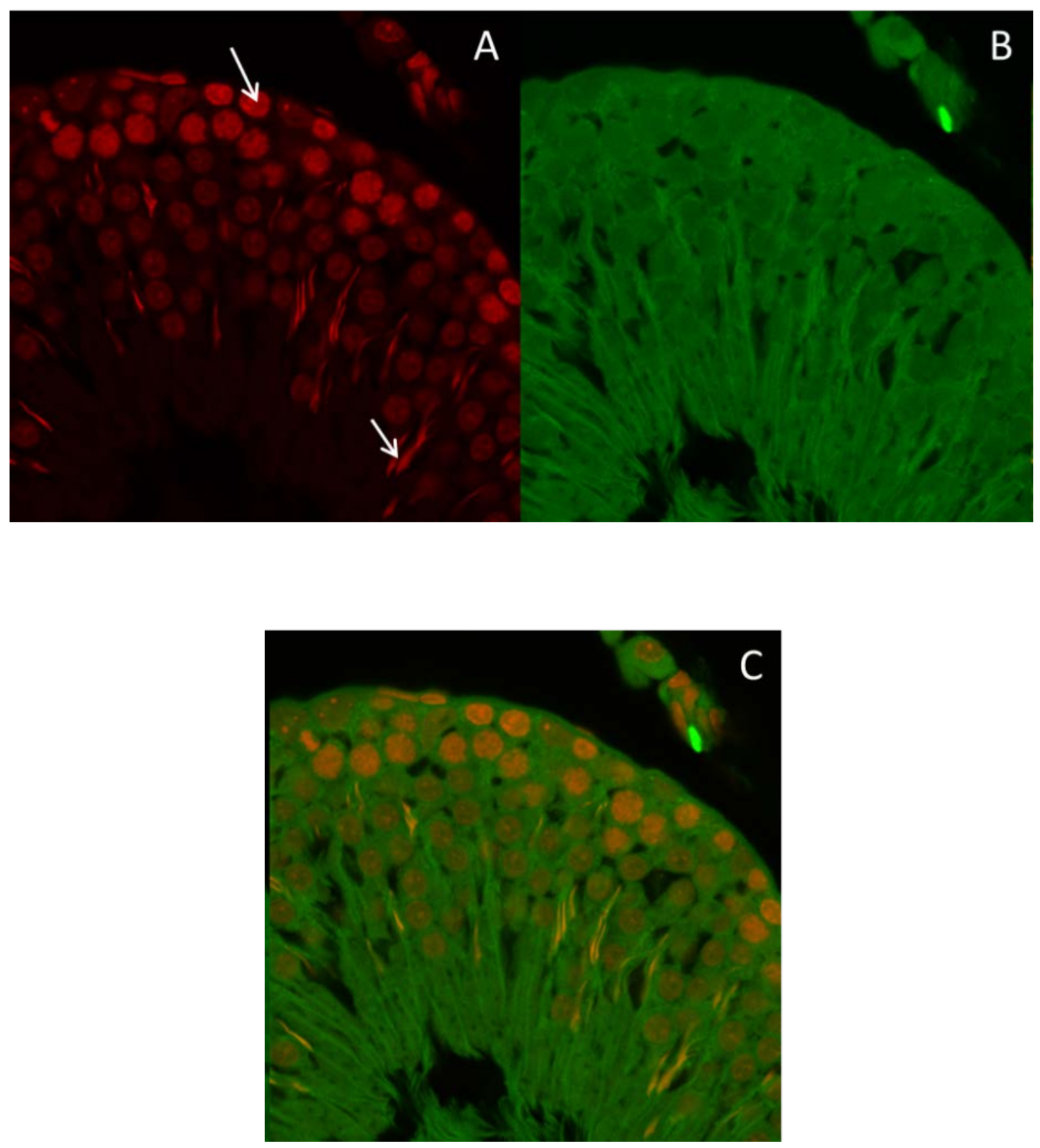

Figura 14. Detección de actina en túbulos seminíferos de rata tratadas con pCA. En A se observa el marcaje de los núcleos con ioduro de propidio (fluorescencia roja) de los distintos tipos de células germinales (flechas). En B se observa el marcaje con el anticuerpo anti-actina (fluorescencia verde). En C se observa la sobreposición de A y B. Micrografías tomadas a 63X. 


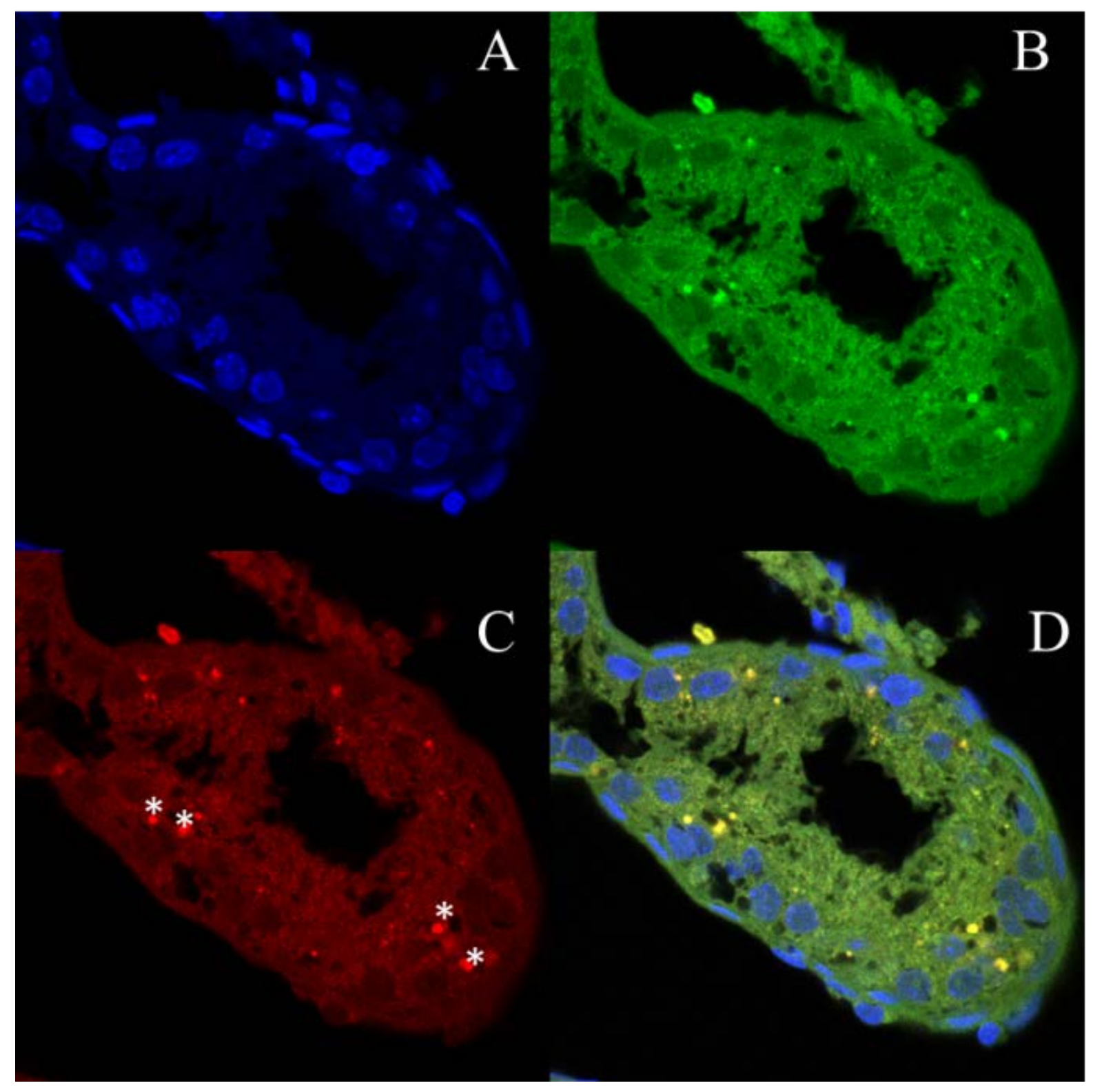

Figura 15. Detección de PARP en túbulos seminíferos de rata tratadas con pCA. En A se observan los núcleos de las distintas células germinales teñidos con Hoechst (fluorescencia azul). En B se observa la tinción del citoplasma con calceína (fluorescencia verde). En C se observan las células positivas a PARP (fluorescencia roja). En D es la sobreposición de A, B y C. Micrografías tomadas a 63X. 

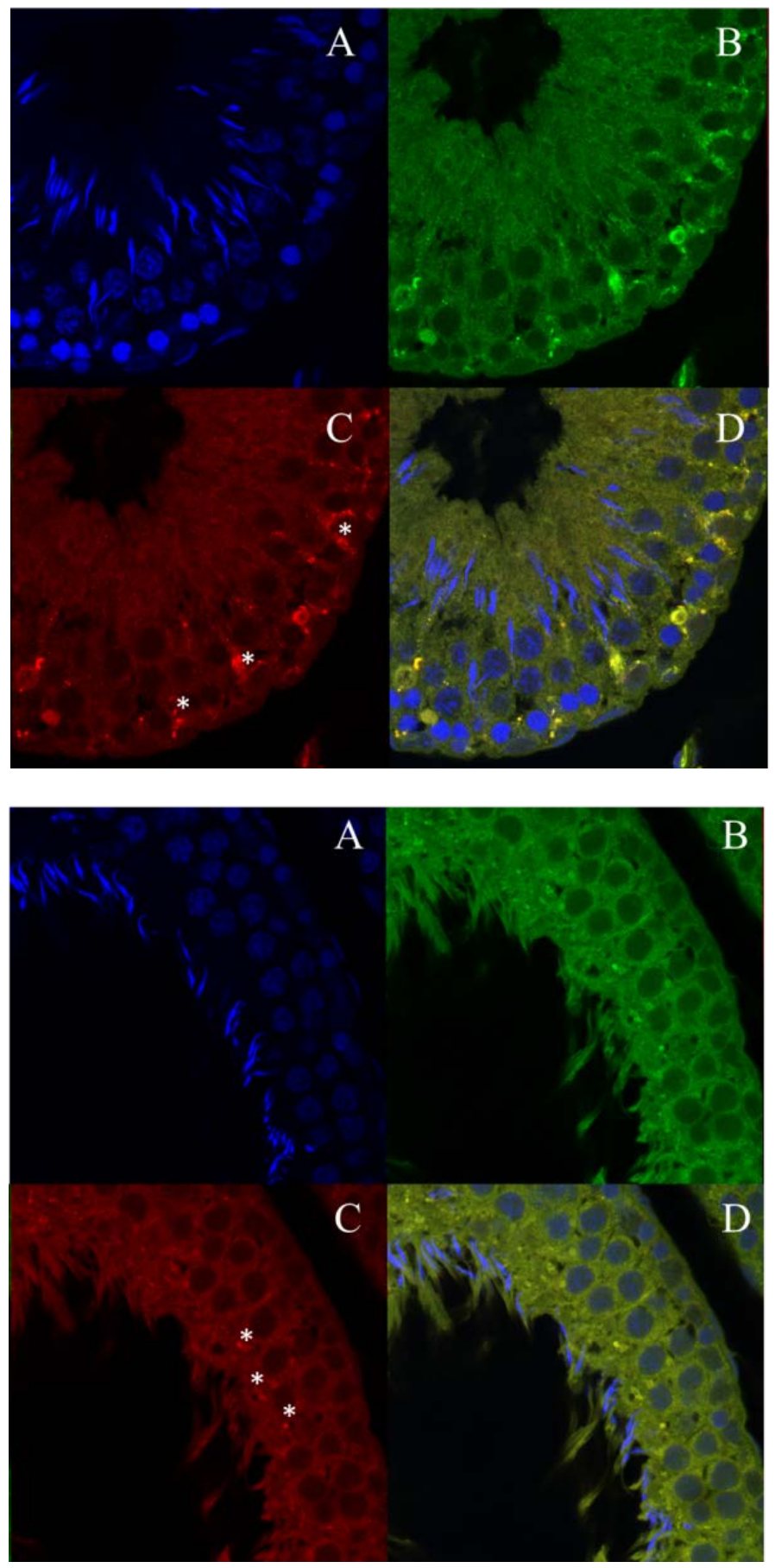

Figura16. Detección de $\alpha$-fodrina en túbulos seminíferos de ratas tratadas con pCA. En A se observan los núcleos de los distintos tipos de células germinales teñidos con Hoechst (fluorescencia azul). En B se observa la tinción del citoplasma con calceína (fluorescencia verde). En C se observan las células positivas a $\alpha$-fodrina (fluorescencia roja). En D se observa la sobreposición de A, B y C. Nótese el marcaje en las células cercanas a la base (imagen superior) y en las células cercanas al lúmen del túbulo seminífero (imagen inferior). Micrografías tomadas a $63 \mathrm{X}$. 


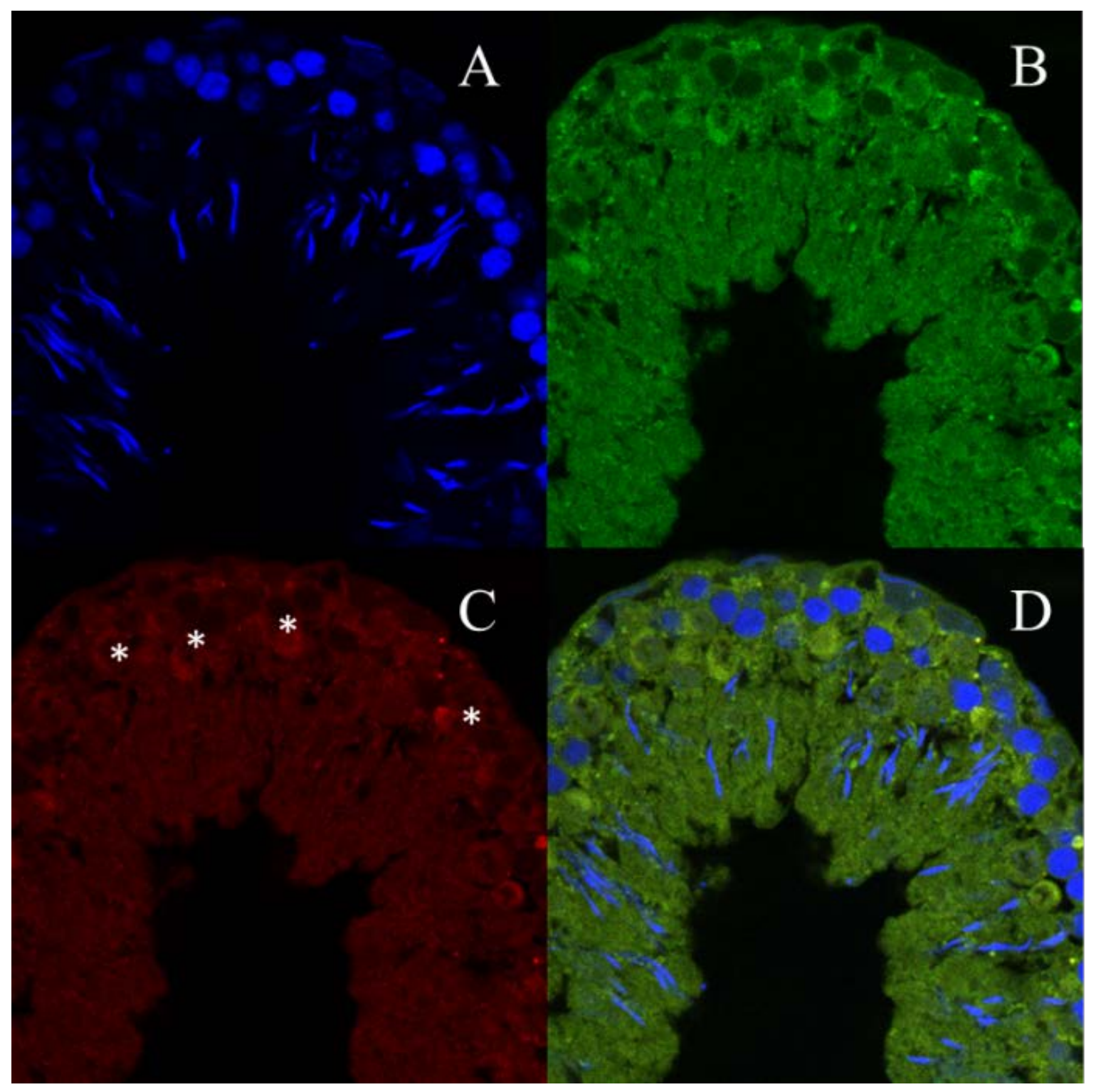

Figura 17. Detección de caspasa 3 en túbulos seminíferos de ratas tratadas con pCA. En A se observan los núcleos de los distintos tipos de células germinales teñidos con Hoechst (fluorescencia azul). En B se observa la tinción del citoplasma con calceína (fluorescencia verde). En C se observan las células positivas a caspasa 3 (fluorescencia roja). En D se observa la sobreposición de A, B y C. Micrografías tomadas a 63X. 
Las imágenes confocales de la detección de PARP en los túbulos seminíferos (Fig. 15) nos permiten observar la presencia de ésta proteína en el núcleo de los diferentes tipos de células germinales, con la sobreposición del marcaje de los núcleos con el marcaje positivo al anticuerpo anti-PARP.

La localización de alfa-fodrina (Fig. 16) se encuentra en las células cercanas al lumen del túbulo seminífero (espermátidas redondas), así como en aquellas células cercanas a la membrana basal, es decir, en espermatogonias o espermatocitos. La caspasa 3 se encuentra localizada en espermatocitos de los túbulos seminíferos (Fig. 17). 


\section{DISCUSIÓN}

Aunque se ha reportado la presencia de caspasas activas en los espermatozoides de diferentes especies, se desconoce cuál es su papel en la función espermática. En el presente trabajo, mediante el uso de un inhibidor fluorescente de caspasas activas se detectó a estas proteasas en los espermatozoides obtenidos de conductos deferentes, mientras que la detección inmunocitoquímica de las caspasas activas y de sus substratos divididos fue negativa. No obstante, se observó histoquímicamente la presencia de las caspasas activas en los diferentes tipos de células germinales testiculares, con excepción del espermatozoide. La detección de alfa fodrina en la región del las espermátidas alargadas que dará origen al cuerpo residual indica claramente que las caspasas activas pueden jugar otros papeles en la espermatogénesis, además de la regulación del número celular.

La apoptosis es el mecanismo por el cual las células dañadas son removidas para mantener la homeostasis tisular en muchos sistemas durante la organogénesis y en la etapa adulta. La presencia de la apoptosis se ha demostrado en el epitelio seminífero, lo que indica que éste proceso también es necesario para la función normal del tejido reproductivo adulto. Además, la apoptosis selectiva de células germinales ocurre para contrarrestar el exceso de proliferación celular durante la espermatogénesis (Marchetti et al., 2002).

Uno de los eventos bioquímicos más importantes durante la apoptosis, es la activación de las caspasas. Las caspasas comprenden una familia de proteasas altamente específicas que contienen una cisteína en su sitio activo. La determinación de la actividad de las caspasas puede ser evaluada mediante diferentes técnicas, como el marcaje con inhibidores fluorescentes (FLICA), la inmunodetección de substratos divididos por caspasas, división de substratos sintéticos, entre otras; las cuales a su vez pueden ser analizadas por microscopía de fluorescencia, confocal y por citometría de flujo (Köhler et al.,2002).

FLICA está diseñado como un ligando con afinidad al centro activo de las caspasas para su detección durante la apoptosis. Su modo de unión involucra la unión covalente a la cisteína del centro activo de la caspasa mediante una fluorometilcetona. El reactivo FLICA es utilizado 
como un marcador temprano de la apoptosis o como una prueba de activación de caspasas (Pozarowski et al., 2003).

En nuestro trabajo la presencia de caspasas 3 y 7 activas en los espermatozoides de rata fue detectada mediante el marcaje con FLICA evaluadas por citometría de flujo en alícuotas con los distintos tratamientos. Aunque Cisternas y Moreno (2006), detectaron la presencia de las caspasas 3, 8 y 9 en espermatozoides de rata, ratón y hámster mediante Western blot, este es el primer reporte de detección de caspasas 3 y 7 activas en los espermatozoides de rata por citometría de flujo. A pesar de que la activación de caspasas puede ser evaluada mediante Western blot, el procesamiento de las caspasas no siempre se correlaciona con la actividad enzimática, por lo que se requiere de un ensayo que determine la actividad enzimática en los espermatozoides.

También se ha reportado la presencia de caspasas activas (3, 7, 8 y 9) en espermatozoides de cerdo (Morales et al., 2010), ovinos (García et al., 2012), y otras especies como caninos (Sokolowska et al., 2009), equinos (Ortega-Ferrusola et al., 2008) y en el humano (Kotwicka et al., 2008).

La sustancia química conocida como imiquimod se utiliza como potente método terapéutico no invasivo para el tratamiento clínico de carcinomas superficiales. Se ha reportado que ejerce actividad directa pro-apoptótica contra varias poblaciones celulares in vitro e in vivo, mediante la activación de la ruta intrínseca de la apoptosis. Sin embargo, hasta la fecha no hay estudios en donde se utilice el imiquimod como inductor de activación de caspasas en espermatozoides, por lo que el presente trabajo es el primero en usarlo para dicho fin con resultados consistentes.

En el presente trabajo, en los espermatozoides de rata, el porcentaje de espermatozoides que expresaron caspasas activas fue mayor cuando los espermatozoides fueron incubados con el inductor (imiquimod) antes de ser teñidos con FLICA comparado con el porcentaje de espermatozoides sólo marcados con FLICA. El porcentaje con expresión de las caspasas 3 y 7 activas fue menor cuando las muestras se trataron con un inhibidor de caspasas (z-DEVD) previo a la incubación con el inductor. Los altos porcentajes de espermatozoides con expresión 
de caspasas activas en presencia de imiquimod, nos indica que dicha sustancia está activando de manera efectiva las caspasas presentes en los espermatozoides.

Anteriormente, en nuestro grupo de trabajo (Pichardo et al., 2010; Morales et al., 2012; García et al.,2012), se emplearon sustancias químicas como inductores de activación de caspasas, entre ellos, el peróxido de hidrógeno, el ácido betulínico y el nitropósido de sodio; sin embargo, los resultados no siempre fueron consistentes. Por lo tanto, de acuerdo a nuestros resultados se propone el uso de imiquimod como un inductor efectivo de activación de caspasas en espermatozoides de rata.

Para corroborar la localización de las caspasas 3 y 7 activas en espermatozoides, se realizó una revisión de las muestras espermáticas por microscopía de fluorescencia. La presencia de caspasas 3 y 7 activas fue observada en la pieza principal del espermatozoide, lo que concuerda con lo reportado por Pichardo et al (2010) quienes además de encontrar actividad de caspasas en la pieza principal, también reportan la región media y ecuatorial con presencia de caspasas activas en espermatozoides de ovino; a diferencia de Weng et al., (2002) quienes reportaron la localización de caspasa 3 en la pieza media en espermatozoides de humano. Se ha visto que las caspasas se encuentran compartimentalizadas en el espermatozoide de los mamíferos en una forma similar a otras enzimas involucradas en rutas de transducciónseñalización y/o en la glucólisis (Cisternas y Moreno 2006).

La detección de la actividad de caspasas y de los substratos de caspasas es una forma de evaluar la apoptosis en células individuales o en tejido. Muchas proteínas son divididas por caspasas durante el proceso apoptótico, la identificación de estos fragmentos de proteínas permiten evaluar indirectamente la activación de caspasas.

Los anticuerpos que reconocen los epítopes expuestos por la división de los substratos de caspasas pueden ser empleados como biomarcadores. Debido a los resultados obtenidos en la técnica de inmunocitoquímica, se realizó la inmunodetección de los fragmentos divididos de las proteínas alfa-fodrina y PARP y de caspasa 3 y actina en túbulos seminíferos de ratas tratadas con pCA mediante inmunohistoquímica, lo que nos permitió detectar la presencia de proteínas blanco de caspasas en los diferentes tipos de células germinales testiculares. 
La actina es una proteína del citoesqueleto presente en todas las células eucariotas. Es requerida durante la espermatogénesis para proveer al espermatozoide en desarrollo de su aparato motor (Aümuller y Seitz 1988). Welch y O’Rand (1985) reportaron la pérdida de filamentos de actina en espermatozoides maduros de conejo, los resultados obtenidos respecto a la ausencia de inmunomarcaje de actina en los espermatozoides de rata, probablemente se deba a la pérdida de éstos filamentos durante la diferenciación espermática, ya que durante este proceso cuando se pierde mucho material citoplasmático que posteriormente pasa a formar los cuerpos residuales.

En el presente trabajo se observó la inmunofluorescencia de actina principalmente en las espermátidas en desarrollo, particularmente asociada a la cara interna de la membrana citoplasmática. El citoplasma de éstas células se eliminará durante la espermiación junto con otros componentes citoplásmicos. Nuestros resultados están en congruencia con lo reportado por Aümuller y Seitz (1985) quienes reportaron la inmunolocalización de actina rodeando la cabeza de las espermátidas en desarrollo y además en las células peritubulares del testículo de rata.

La membrana plasmática del espermatozoide es un mosaico de dominios, los cuales se establecen durante la espermiogénesis a través de interacciones con el citoesqueleto cortical de actina y proteínas de unión tanto a actina como fodrina (Virtanen et al., 1984). En los espermatozoides de humanos y de ovinos se ha reportado la presencia de actina en diferentes regiones del espermatozoide como el flagelo, el cuello y la región postacrosomal (Virtanen et al., 1984; de las Heras et al., 1997). En nuestro trabajo identificamos la presencia y la distribución de la alfa-fodrina en los diferentes tipos de células germinales testiculares. Nuestros resultados son consistentes con lo previamente reportado por De Cesaris et al (1989), quienes describieron la ausencia de inmunofluorescencia en los espermatozoides testiculares y del epidídimo de rata y la presencia de inmunofluorescencia en espermatocitos y espermátidas redondas, donde dicha fluorescencia se encontraba asociada a la membrana plasmática. Como se puede observar en nuestros resultados, el citoplasma de estas células aparece teñido de manera difusa, mientras que el núcleo no está marcado. Dicho marcaje podría estar definido por las diferentes etapas del ciclo del epitelio seminífero. 
La reducción de citoplasma en las etapas finales de la espermatogénesis y junto con él, la perdida de material citoplásmico y componentes celulares, podría ser la razón por la cual la fodrina parece perderse en los espermatozoides. Dicha observación estuvo presente tanto en los experimentos de inmunocitoquímica como de inmunohistoquímica.

En células somáticas, la división de alfa-fodrina podría contribuir a los cambios morfológicos, debido a que la fodrina es un componente principal del citoesqueleto cortical. Se ha reportado que la formación de burbujas en la membrana plasmática es uno de los cambios morfológicos presentes después de la división de alfa-fodrina. Se sabe además, que la presencia y activación de la caspasa 3 es requerida para que se lleve a cabo la división de alfa-fodrina in vivo en diferentes tipos celulares como timocitos y líneas celulares cancerígenas.

La presencia de caspasa 3 fue localizada en las células germinales testiculares como los espermatocitos. Su localización concuerda con lo reportado para la presencia de caspasas activas e inactivas en cualquier tipo celular. Se sabe que las células germinales apoptóticas pueden estar presentes en todas las etapas de la espermatogénesis, aunque las espermatogonias y espermatocitos son probablemente los principales blancos de la apoptosis tanto en situaciones fisiológicas como patológicas (Tapia y Peña 2009).

La detección de la caspasa 3 presente en los espermatozoides de rata cuando estos son evaluados mediante citometría de flujo, representa una aparente discrepancia, la cual podría explicarse por los distintos métodos de marcaje utilizados. Los espermatozoides se evaluaron mediante citometría de flujo, marcados con el reactivo FLICA, mientras que el tejido testicular fue evaluado por inmunohistoquímica. A pesar de que el marcaje con FLICA es una prueba de detección de caspasas activas, se debe tener cuidado en cuanto a la interpretación de su unión como exclusiva al sitio activo de las caspasas debido a que también se puede unir a proteínas de peso molecular similar a la subunidad grande de las caspasas o incluso a otros componentes celulares (Pozarowski et al., 2003; Pichardo et al., 2010). La inmunohistoquímica es una herramienta usada para localizar antígenos específicos en secciones de tejido con anticuerpos marcados basado en la interacción antígeno-anticuerpo. 
La división de PARP-1 se ha utilizado como un marcador de apoptosis. Se ha reportado su presencia en los diferentes tipos de células germinales; sin embargo, su presencia en el espermatozoide eyaculado no es clara. Nuestros resultados nos permiten sugerir que la localización de PARP-1 se encuentra principalmente en espermatocitos, lo que está en concordancia con lo reportado por Di Meglio et al (2004). La actividad de PARP es necesaria para la expresión génica coordinada en la matriz nuclear (Tramontano et al., 2005). En congruencia con lo anterior, Maymon et al (2006) reportaron la expresión de PARP-1 en células germinales testiculares, principalmente en espermatocitos primarios, espermátidas redondas y alargadas en testículo de humano.

La presencia de PARP-1 en los espermatozoides de rata no es clara; sin embargo, se ha reportado que su división es llevada a cabo por caspasas en los espermatozoides eyaculados de humano. La división de PARP es realizada por la caspasa 3 activa, la cual inicia la apoptosis y previene el proceso de reparación de ADN mediado por PARP (Jha et al., 2009).

Nuestros resultados indican la presencia de caspasas 3 y 7 en los diferentes tipos de células germinales de la rata macho, así como de los fragmentos divididos de alfa-fodrina y de PARP evaluados mediante distintos métodos de detección.

Existen reportes en donde se ha observado que los anticuerpos no son tan específicos como advierte el fabricante. Este problema podría en parte explicar por qué algunos experimentos no son reproducibles (Bordeaux et al., 2010). Sin embargo, la validación de los anticuerpos no es un factor determinante en la ausencia de marcaje positivo en los espermatozoides de rata para los anticuerpos utilizados. Probablemente, en los espermatozoides de esta especie no se presentan las proteínas en su forma completa o en su forma dividida o incluso, que las caspasas no se encuentran en los espermatozoides tal y como fue demostrado por los ensayos de inmunocitoquímica. Por lo tanto, existe controversia en cuanto a la detección de caspasas 3 y 7 activas en los espermatozoides de rata mediante citometría de flujo y la no detección de esta enzima en los diferentes tipos de células germinales testiculares mediante inmunohistoquímica. 
Aunque, como se mencionó anteriormente, la apoptosis es una forma característica de muerte celular que sirve para eliminar células innecesarias y potencialmente peligrosas, hay estudios donde los eventos parecidos a la apoptosis no llevan a la muerte sino que están involucrados en la diferenciación terminal de ciertos tipos celulares (Arama et al., 2003; D’Amelio et al., 2010).

Las caspasas en células somáticas y germinales participan en el proceso apoptótico; sin embargo, su papel en los espermatozoides no es claro. Se ha observado que la mera presencia de caspasas activas no es un factor crucial letal en el espermatozoide eyaculado (Tapia y Peña, 2006), por lo que se podría especular que las caspasas activas tienen un papel fisiológico en el espermatozoide maduro más que estar involucradas en la muerte por apoptosis. En el caso de la rata, existe poca información que documente la presencia y la función de las caspasas en los espermatozoides.

Se ha hipotetizado que un proceso apoptótico alterado pueda estar asociado con la infertilidad masculina; sin embargo, no es claro si este proceso en espermatozoides y células somáticas ocurre de manera similar, y si los espermatozoides entren en un proceso apoptótico abortivo el cual podría ser iniciado en el testículo (Sakkas et al., 1999). Los espermatozoides durante la espermiación pierden casi por completo su contenido citoplásmico y presentan un núcleo haploide altamente condensado; debido a su particular composición celular los espermatozoides no presentan apoptosis tal y como es definida para las células somáticas, por lo que la presencia de características apoptóticas, como lo es la expresión de caspasas activas, puedan tener un papel no apoptótico en procesos reproductivos como la fertilización.

Tradicionalmente se ha sugerido que las caspasas son el centro del programa apoptótico; sin embargo, existen reportes que indican que la activación de caspasas no conduce necesariamente a la muerte celular. La caspasa 3 está involucrada en procesos diferentes a la apoptosis como la diferenciación de queratinocitos embrionarios, de células madre neuronales, macrófagos y osteoblastos (Sordet et al., 2002; Okuyama et al., 2004; Fernando et al., 2005; Miura et al., 2004); mientras que la actividad de las caspasas (3 y 9) es requerida para llevar a cabo la diferenciación de espermátidas en D. melanogaster (Arama et al., 2010). 
Un incremento en la actividad de la caspasa 3 está asociado a la diferenciación de las células cancerígenas (K562) y no a la apoptosis (Sztiller-Sikorska et al., 2009). La activación de caspasa 3 media funciones no apoptóticas neuronales como la plasticidad sináptica, regeneración dendrítica, así como en procesos de aprendizaje y memoria (D’Amelio et al., 2010).

La diferenciación terminal del espermatozoide en mamíferos comparte características morfológicas y bioquímicas con la apoptosis. Sin embargo, más que causar la muerte son usadas para eliminar específicamente componentes citoplásmicos, como los conocidos cuerpos residuales, los cuales se ha reportado que presentan caraterísticas apoptóticas (BlancoRodriguez y Martínez-García 1999).

\section{CONCLUSIÓN}

No es posible detectar mediante inmunocitoquímica a la caspasa 3 y a los fragmentos divididos de las proteínas $\alpha$-fodrina y PARP en los espermatozoides de rata; sin embargo, si es posible detectar a esas proteínas en los diferentes tipos de células germinales testiculares.

\section{COMENTARIO}

El empleo de distintos métodos de detección nos permite la obtención de resultados diferentes en cuanto a la detección de caspasa 3 en los espermatozoides de rata. 


\section{REFERENCIAS}

Aitken J y Baker M. Causes and consequences of apoptosis in spermatozoa; contributions to infertility and impacts on development. Int. J. Dev. Biol. 2013. 57:265-272.

Alshahrani S, McGill J y Agarwal A. Prostatitis and male infertility. Journal of Reproductive Immunology. 2013.

Amman R y Hammerstedt R. Detection of differences in fertility. Journal of Andrology. 2002. 23 (3):317-325.

Aragón MA, Ayala ME, Marín M, Avilés A, Damián-Matsumura P, Domínguez R. Serotoninergic system blockage in the prepubertal rat inhibits spermatogenesis development. Reproduction. 2005. 129, 717-727.

Aragón MA, Becerril ML. El espermatozoide y los marcadores de calidad espermática. En: Avances en Biología de la Reproducción 2012. Primera edición. Eds. Universidad Autónoma Metropolitana, Iztapalapa. 2012.

Arama E, Agapite J, Steller H. Caspase activity and s specific cytochrome C are required for differentiation in Drosophila. Developmental Cell. 2003. 4, 687-697.

Aümuller G y Seitz J. immunocytochemical localization of actin and tubulin in rat testis and spermatozoa. Histochemistry. 1988; 89(3): 261-267.

Bejarano I, Lozano G, Ortiz A. Caspase 3 activation in human spermatozoa in response to hydrogen peroxide and progesterone. Fertility and Sterility. 2008; 90:759-770.

Bennet V, Gilligan DM. The spectrin-based membrane skeleton a micron scale organization of the plasma membrane. Annu. Rev. Cell. Biol. 1993. 9: 27-66.

Bjelakovic G, Nagorni A, Bjelakovic M, Stamenkovic I, Arsic R, Katic V. Apoptosis: Programmed cell death and its clinical implications. Facta Universitatis. Series: Medicine and Biology. 2005; 12:6-11. 
Blanco-Rodriguez J, Martinez-Garcia C. Apoptosis is physiologically restricted to a specialized cytoplasmic compartment in rat spermatids. Biology of Reproduction. 1999. 61, 1541-1547.

Boatright M, Salvesen S. Mechanism of caspase activation. Current Opinion in Cell Biology. 2003; 15:725-731.

Bordeaux J, Welsh A, Agarwal S, Killiam E, Baquero M, Hanna J, Anagnostou V y Rimm D. BioTecniques. 2010; 48:197-209.

Brugnon F, Ouchchane L, Verheyen G, Communal Y, Van der Elst J, Tournaye H, Janny L, Grizard G. Fluorescence microscopy and flow cytometry in measuring activated caspases in human spermatozoa. International Journal of Andrology. 2007, 32: 265-273.

Brum A, SabeurK, Ball B. Apoptotic-like changes in equine spermatozoa separated by density-centrifugation or after cryopreservation. Theriogenology. 2008; 69:1041-1055.

Camatini M, Anelli G y Casale A. Identification of actin in boar spermatids and spermatozoa by immunoelectron microscopy. Europan Journal of Cell Biology. 1986; 42:311-318.

Celik-Ozencil C y Tasatargil A. Role of poly(ADP-ribose) polymerases in male reproduction. Spermatogenesis. 2013. 3:1

Chausiaux OE, Abel MH, Baxter FO, Khaled WT, Ellis PJ, Charlton HM y Affara NA. Hypogonadal mouse, a model to study the effects of the endogenous lack of gonadotrophinas on apoptosis.Biology of Reproduction. 2008; 78:77-90.

Chaveiro A, Santos P y da Silva F. Assessment of sperm apoptosis in cryopreserved bull semen after swim-up treatment: A flow cytometric study. Reprod Dom Anim. 2007. 42:17-21.

Chowdhury I, Tharakan B, Bhat G. Caspases- An update. Comparative Biochemistry and Physiology. 2008. 151: 10-27.

Cisternas P, Moreno R. Comparative analysis of apoptotic pathways in rat, mouse and hamster spermatozoa. Molecular Reproduction and Development. 2006. 73: 1318-1325. 
Comhaire F. Methods to evaluate reproductive health of the human male. Male Reproductive Toxicity. 1993. 7:39-46.

Cooke H y Saunders P. Mouse models of male infertility. Nature Reviews. Genetics. 2002. 3 (10):790-801.

Crawford E, Wells J. Caspase substrates and cellular remodeling. Annual Reviews Biochemistry. 2011; 80:1055-1087.

D’Amelio M, Cavallucci V, Cecconi F. Neuronal caspase-3 signaling: not only cell death. Cell Death and Differentiation. 2010, 17: 1104-1114.

Darzynkiewicz Z, Pozarowski P, Lee B, Johnson G. Fluorochrome-labeled inhibitors of caspases: Convenient in vitro and in vivo markers of apoptotic cells for cytometric analysis. Methods Mol Biol. 2011. 682: 103-114.

De Cesaris P, Flippini A, Stefanini M, Ziparo E. Spectrin, fodrin and protein 4.1-like proteins in differentiating rat germ cells. Differentiation. 1989.41:216-222.

De las Heras MA, Valcarcel A, Perez LJ y Moses DF. Actin localization in ram spermatozoa: effect of freezing/thawing, capacitation and calcium ionophore-induced acrosomal exocytosis. Tissue Cell. 1997. 29:47-53.

Di Meglio S, Tramontano F, Cimmino G, Jones R, Quesada P. Poly(ADP-ribose) polymerase1 and 2 poly (ADP-ribose) glycohydrolase as DNA repair and proapoptotic factor in rat germinal cells exposed to nitric oxide donors. BBS Mol Cell Res. 2004. 1692(1):35-44.

Dwinell M, Lazar J y Geurts A. The emerging role for rat models in gene discovery. Mammam Genome. 2011. 22(0):466-475.

Earnshaw W, Martins L, Kaufmann S. Mammalian caspasas: Structure, activation, susbtrates, and functions during apoptosis. Annual Reviews Biochemistry. 1999; 68:383-424.

Eddy EM. The spermatozoon. En: Knobil and Neill's. Physiology of Reproduction. Eds. Neill JD. $3^{\circ}$ edición. Elsevier Academic Press. USA. 2006. Pp 3-38. 
Erkkila K, Pentikainen V, Wikstrom M, Parvinen M, Dunkel L. Partial oxygen pressure and mitochondrial permeability transition affect germ cell apoptosis in the human testis. J. Clin Endocrinol. Metabol. 1999. 84: 4253-4259.

Evenson DP, Larson KL, Jost LK. Sperm chromatin structure assay: its clinical use for detection sperm DNA fragmentation in male fertility and comparisions with other techniques. Journal of Andrology. 2002. 23: 25-43.

Faleiro L, Lazebnick Y. Caspases disrupted the nuclear-cytoplasmic barrier. The Journal of Cell Biology.2000.151: 951-959.

Fernando P, Brunette S., Megeney L. Neural stem cell differentiation is dependent upon endogenous caspase 3 activity. FASEB Journal. 2005; 19:1671-1673.

Fink S y Cookson B. Apoptosis, pyropotosis and necrosis: Mechanistic description of dead and dying eukaryotic cells. Infection and Immunity. 2005. 73(4):1907-1916.

Flormann $\mathrm{H}$ y Ducibella T. Fertilization in mammals. Capit. 2. En: Physiology of Reproduction. Edit. Knobills y Neills. 2006.

Fox J, Reynolds C, Morrow J, Philips D. Spectrin is associated with membrane-bound actin filaments in platelets and is hydrolyzed by the $\mathrm{Ca} 2+$ dependent protease during platelet activation. Blood. 1987, 69: 537-545.

Fuentes-Prior P, Salvesen G. The protein structures that shape caspase activity specificity activation and inhibition. Biochem J. 2004, 384: 201-232.

García G, Morera J, Monzó A, Morales G, Fernández P, Pellicer A y Jiménez F. The male factor of the infertility: the role of the urologist in an Assisted Reproduction Deparment. Revista Iberoamericana de Infertilidad. 2010. 27:513-521.

García S, Aragón A, Flores-Alonso JC. Confocal microscopy and image analysis indicates a region-specific relation between active caspases and cytoplasm in ejaculated and epididymal sperm. Plos One. 2012; 7(4). 
Garner DL, Thomas CA, Joerg HW, Dejarnette JM, Marshall CE. Fluorometric assesment of mitochondrial function and viability in criopreserved bovine spermatozoa. Biology of Reproduction. 1997; 57:1401-1406.

Givan A. Flow Cytometry: An introduction. En: Flow cytometry protocols, methods in molecular biology. Edits. Hawley T y Hawley R. 2011.

Graham J. Assessment of sperm quality: a flow cytometric approach. Animal Reproduction Science. 2001; 239-247.

Grunewald S, Sharma R, Paasch U, Glander HJ, Agarwal A. Impact of caspase activation in human spermatozoa. Microscopy research and technique. 2009, 72: 878-888.

Hess R y Da Franca L. Spermatogenesis and cycle of the seminiferous epithelium. Capít.1. En: Molecular Mechanism in Spermatogenesis. Edit. Yan Cheng. 2008.

Huang SW, Chang CC, Lin CC, Tsai JJ, Chen YJ, Wu CY, Liu KT, Shieh JJ. Mcl-1 determines the imiquimod-induced apoptosis but not imiquimod-induced autophagy in skin cancer cells. Journal of Dermatology Science. 2012, 65: 170-178.

Huckins C. The morphology and kinectics of spermatogonial degeneration in normal adult rats: an analysis using a simplified classification of the germinal epithelium. Anatomical Record. 1978; 190:905-926.

Huesmann G y Clayton D. Dynamic role of postsynaptic caspase 3and BIRC4 in zebra finch song response habituation. 2006. Neuron. 52(6):1061-1072.

Huhtaniemi I y Bartke A. Perspective: Male reproduction. Endocrinology. 2001. 142:21782183.

Janicke R, Patrick N, Spregnart M, Porter A. Caspase-3 is required for alpha-fodrin cleavage but dispensable for cleavage of other death substrates in apoptosis. TheJournal of Biological Chemistry. 1998, 273: 15540-15545. 
Jha R, Agarwal A, Mahfouz R, Paasch U, Grunewald S, Sabanegh E, Yadav S, Sharma R. Determiantion of poly (ADP-ribose) polymerase (PARP) homologues in human ejaculated sperm and its correlation with sperm maduration. Fertility and Sterility. 2009, 91: 782-790.

Kanduc D, Mittelman A, Serpico R, Sinigaglia E, Sinha A, Natale C, Santacroce R, Di Corcia M, Lucchese A, Dini L, Pani P, Santacroce S, Simone S, Bucci R y Farber E. Cell Death: Apoptosis versus necrosis (review). International Journal of Oncology.2002. 21(1): 165-170.

Kawa, S. Apoptosis y hormonas esteroides. Revista Hospital General Dr. M Gea González. 2000. 3:115-117.

Kerr JF, Wyllie AH, Currie AR. Apoptosis: A basic biological phenomenon with wideranging implications in tissue kinetics. Br. J. Cancer.1972; 26: 239-258.

Kort H, Massey J, Elsner C, Mitchell-Leef D, Shapiro D, Witt M y Roudebush W. Journal of Andrology. 2006. 27:450-452.

Kotwicka M. Caspase 3 activation and phosphatidylserine membrane translocation in human spermatozoa: is there a relationship? Reproductive BioMedicine Online. 2008; 5:657-663.

Köhler C, Orrenius S, Zhivotovsky B. Evaluation of caspase activity in apoptotic cells. Journal of Immunological Methods. 2002; 26:97-110.

Kroemer G, El-Deiry W, Golstein P, Peter M, Vaux D, Vandenabeele P, Zhivotovsky B, Blagosklonny M, Malorni W, Knight R, Piacentini M, Nagata S y Melino G. Cell Death and Differentiation. 2005. 12:1463-1467.

Kroemer G, Galluzzi L, Vandenabeele P, Abrams J, Alnemri E, Baehrecke E, Blagosklonny M, El-Deiry W, Golstein P, Green D, Hengartner M, Knight R, Kumar S, Lipton S, Malorni W, Nuñez G, Peter M, Tschopp J, Yuan J, Piacentini M, Zhivotovsky B y Melino G. Classification of cell death: recommendations of the Nomenclature Committee on Cell Death. Cell Death Differ. 2009. 16(1): 3-11.

Laemmli UK. Cleavage of structural proteins during the assembly of the head of bacteriophage T4. Nature.1970, 227, 680-685. 
Levek-Motola N, Soffer Y, Shochat L, Raziel A, lewin LM, Golan R. Flow cytometry of human semen: a preliminary study of a non-invasive method for the detection of spermatogenetic defects. Human Reproduction. 2005; 20:3469-3475.

Mahfouz R, Sharma R, Poenicke K, Jha R, Paasch U, Grunewald S, Agarwal A. Evaluation of poly(ADP-ribosa) polymerase cleavage (CPARP) in ejaculated human sperm fractions after induction of apotosis. Fertility and Sterility. 2009; 91: 2210-2220.

Marchetti C, Obert G, Deffosez A, Formstecher P, Marchetti P. Study of mitochondrial membrane potential, reactive oxygen species, DNA fragmentation and cell viability by flow cytometry in human sperm. Human Reproduction. 2002; 17: 1257-1265.

Marchetti P, Marchetti C. Impact and significance of apoptosis in human ejaculated spermatozoa. En: Frontiers in cell apoptosis research. Erlich SR (Ed). Nova Medical, N.Y. 2007; 125-138.

Martin S, O’Brien G, Nishioka W, McGahon A, Mahboubi A, Saido T, Green D. Proteolysis of fodrin (Non-erythroid spectrin during apoptosis). The Journal of Biological Chemistry. 1995. 270: 6425-6428.

Martin-Oliva D, Muñoz-Gámez J, Aguilar- Quesada R, Ruiz M, Oliver F. Poli(ADP-ribosa) polimerasa-1: Una proteína nuclear implicada en procesos inflamatorios, muerte celular y cancer. Médica UIS. 2006. 19:95-103.

Morales C, Aragón A, Pescador N, Salazar F. Swim-up procedure in boar semen improves motility and viability but recorvered spermcould carry active caspase and chromatine damage. Journal of Animal Veterinary Advances. 2012; 11(4):431-437.

Moreno R, Lizama C, Urzúa N, Vergara S, Reyes J. Caspase activation throughout the first wave of spermatogenesis in the rat. Cell Tissue Res. 2006, 325: 533-540.

Mortimer S. CASA. Practical aspects. Journal of Andrology. 2000.

Nicholson D. Caspase structure, proteolytic substrates, and function during apoptotic cell death. Cell Death and Differentiation. 1999; 6:1028-1042. 
O’Donell OL, Meachem JS; Stanton GP, McLachlan R. Endocrine regulation of spermatogenesis. En: Knobill and Neill's Physiology of Reproduction. Eds. Neill JD. $3^{\circ}$ ed. Elsevier Academic Press USA. 2006. pp. 1017-1021.

Ortega-Ferrusola C, Sotillo-Galán Y, Varela-Fernández E, Gallardo-Bolaños JM, Muriel A, González-Fernández L, Tapia A y Peña F. Detection of apoptosis like changes during the cryopreservation process in equine sperm. Journal of Andrology. 2008; 29:213-221.

Ouyang L, Shi Z, Zhao s, Wang F, Zhou T, Liu B y Bao K. Programmed cell death pathways in cancer: a review of apoptosis, autophagy and programmed necrosis. Cell Prolif. 2012; 45:487-498.

Paasch U, Grunewald S, Fitzl G, Glander HJ. Deterioration of plasma membrane is associated with activated caspases in human spermatozoa. Journal of Andrology. 2003; 24:246-252.

Pesch S y Bergmann M. Strucuture of mammalian spermatozoa in respect to viability, fertility and cryopreservation. 2006. Micron. 37:597-612.

Pereira WO, Amarante-Mendes GP. Apoptosis: A programme of cell death or cell disposal? Scandinivian Journal of Immunology. 2011; 73:401-407.

Perticarari S, Ricci G, Granzotto M, Boscolo R, Pozzobon C, Guarnieri S, Sartore A, Presani G. A new multiparameter flow cytometric method for human semen analysis. Human Reproduction. 2007, 22: 485-494.

Pichardo A, Aragón A, Ayala-Escobar M, Dominguez-Vara I. Viability tests, active caspasas 3 and -7, and chromatine structure in ram sperm selected using the swim-up procedure. Journal of Andrology. 2010; 31: 169-176.

Print C y Loveland K. Germ cell suicide: New insights into apoptosis during spermatogenesis. 2000. BioEssays. 22:423-430.

Ried S, Scott F. Caspases: Activation, Regulation and Function. En: Essentials of Apoptosis. Springer. 2009. 3-24. 
Ruwanpura S, McLachlan, Meachem S. Hormonal regulation of male germ cell development. Journal of Endocrinology. 2010; 205: 117-131.

Saikumar P, Venkatachalam M.A. Capítulo 4. Apoptosis and cell death. En: Basic Concepts of Molecular Pathology, Molecular Pathology Library 2. Eds.Cagel P, Allen TC. Springer Science. 2009.

Sakkas D, Mariethoz E, John J. Abnormal sperm parameters in humans are indicative of an abortive apoptotic mechanism linked to the Fas-mediated pathway. Experimental Cell Research. 1999; 251: 350-355.

Sakkas D. Abnormal spermatozoa in the ejaculated: abortive apoptosis and faulty nuclear remodeling during spermatogenesis. Reproductive BioMedicine Online. 2003, 7: 428-432.

Schön M, Bong A, Drewniok C, Herz J, Geilen C, Reifenberger J, Benninghoff B, Slade H, Gollnick H, Schön M. Tumor selective induction of apoptosis and the small molecule immune response modifier imiquimod. Journal of the National Cancer Institute. 2003, 95: 1138-1149.

Shi Y. Strucutural biology of programmed cell death. En: Essentials of Apoptosis. Aguide for basic and clinical research. Editores: Ming-Yin X y Dong Z. $2^{\circ}$ edición. Humana Press. 2009.

Signore M, Reeder A. Antibody validation by western blotting. En: Molecular Profiling: Methods and Protocols, Methods in Molecular Biology. Eds. Espina V, Liotta L. Springer Science. 2012, 83: 139-155.

Smolewski P, Grabarek J, Lee B, Johnoson G, Darzynkiewicz Z. Kinetics of HL-60 cell entry to apoptosis during treatment with TNF- $\alpha$ or camptothecin assayed by the stathmo-apoptosis method. Cytometry. 2002; 47:143-149.

Sordet O, Rebé C, Plenchette S, Zermati Y, Hermine O, Vainchenker W, Garrido C, Solari E y Dubrez-Daloz L. Specific involvement of caspases in differentiation of monocytes into macrophages. Blood. 2002; 100:4446-4453.

Stennicke H, Salvesen G. Caspases-controling intracellular signals by protease zymogen activation. Biochimica et Biophysica Acta. 2000; 299-306. 
Sztiller-Sikorska M, Jakubowska J, Wozniak M, Stasiak M, Czyz M. A non apoptotic function of caspase 3 in pharmacologically-induced differentiation. British Journal of Pharmacology. 2009. 157:1451-1462.

Sutovsky P y Manandhar G. Mammalian spermatogenesis and sperm structure: anatomical and compartmental analysis. Capítulo 2. En: Sperm cell. Edit. C. De Jonge y C. LR. Barrat. 2006.

Tapia J, Peña F. Apoptotic events in male germ cells and in mature mammalian spermatozoa. En: Apoptosis: Involvement of Oxidative Stress and Intracellular Ca2+ Homeostasis. Salido G y Rosado J (Eds.). 2009: 165-201.

Taylor L, Weng S, Fox P, Duran H, Morshedi S, Oehninger S, Beebe J. Somatic cell apoptosis markers and pathways in human ejaculated sperm: potential utility as indicators of sperm quality. Molecular Human Reproduction. 2004; 10:825-834.

Tesarik J, Ubaldi F, Rienz L, Martinez F, Iacobelli m, Mendoza C y Greco E. Caspasedependent and independent DNA fragmentation in Sertoli and germ cells from men with primary testicular failure: relationship with histological diagnosis. Human Reproduction. 19:254-261.

Ulukaya E, Acilan C, Yilmaz Y. Apoptosis: why and how does it occur in biology?. Cell Biochemistry and Function. 2011; 29:468-480.

Vaculova A, Zhivotovsky B. Caspases: Determination of their activities in apoptotic cells. Methods in Enzymology. 2008, 442:157-181.

Virtanen I, Badley A, Passivuo R y Lehto V. Distinct cytoskeletal domains revealed in sperm cells. The Journal of Cell Biology. 1984; 99:1083-1091.

Welch J y O'Rand M. Identification and distribution of actin in spermatogenic cells and spermatozoa of the rabbit. Developmental Biology. 1985; 109:411-417.

Weng SL, Taylor L, Morshedi M, Shuffner A, Duran EH, Beebe S, Oehninger S. Caspase activity and apoptotic markers in ejaculated human sperm. Molecular Human Reproduction. 2002, 8:984-991 
Wundrich K, Paasch U, Leicht M, Glander HJ. Activation of caspases in human spermatozoa during cryopreservation- an immunoblot study. Cell and Tissue Banking. 2006, 7:81-90.

Wyllie A. Where, o death, is thy Sting? A brief review of apoptosis biology. Mol Neurobiology. 2010. 42:4-9.

Wyrobek A. Methods and concepts in detecting abnormal reproductive outcomes of paternal origin. Male Reproductive Toxicity.1993. 7:3-16. 